\title{
Influence of the fly ash fraction after grinding process on the hydrothermal synthesis efficiency of Na-A, Na-P1, Na-X and sodalite zeolite types
}

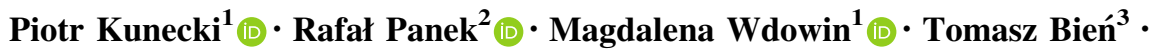 \\ Wojciech Franus ${ }^{2}$ (D)
}

Received: 9 October 2019/Revised: 29 March 2020/Accepted: 13 May 2020/Published online: 8 June 2020

(C) The Author(s) 2020

\begin{abstract}
The fly ashes (Class F and C) have been successfully used as the main substrates in the hydrothermal syntheses of $\mathrm{Na}-\mathrm{A}, \mathrm{Na}-\mathrm{P} 1, \mathrm{Na}-\mathrm{X}$ and sodalite zeolites. Both ashes and their derivatives after milling with magnetic field grinder were used. The paper investigates the effect of fly ash fraction size on the syntheses efficiency and physicochemical properties of the obtained zeolites. The starting material and obtained zeolites were subjected to physicochemical characteristics using $\mathrm{X}$-ray diffraction, X-ray fluorescence, particle size analysis, and scanning electron microscopy methods. The paper showed a significant effect of the used fly ash fractions on the quantity, purity, quality and level of crystallinity of the zeolites phase obtained. The application of the grinding process prior to the syntheses of zeolites, with a relatively small financial outlay, significantly increases their application potential. Obtained zeolites are a promising material in the context of their use, inter alia, in environmental protection.
\end{abstract}

Keywords Grinding degree · Magnetic field grinder · Fly ash · Synthetic zeolites · Hydrothermal synthesis

\section{Introduction}

Nowadays, the generation of electricity is one of the main factors driving the development of the economy. The Polish energy sector is based mainly on the combustion processes of fossil fuels such as hard coal and lignite. Mining yield of these fuels in 2014-2018 in Poland reached the level of 73.3, 72.7, 70.8, 66, 58.6 million tonnes for hard coal and 63.9, 63.1, 60.2, 61.2, 63.8 million tonnes for lignite, respectively (Central Statistical Office 2015, 2016, 2017, 2018, 2019). In 2016, Poland had the

Piotr Kunecki

pkunecki@min-pan.krakow.pl

$1 \quad$ Mineral and Energy Economy Research Institute, Polish Academy of Sciences, Wybickiego 7a, 31-261 Kraków, Poland

2 Lublin University of Technology, Nadbystrzycka 40, 20-618 Lublin, Poland

3 BIKO-SERWIS sp. z o.o. spółka komandytowa, Zakładowa 13, 26-052 Nowiny, Poland leading position in terms of hard coal production and was the second largest producer of lignite, after Germany (171.5 tonnes) (EURACOAL statistics 2019a). Despite the growing role of renewable energy sources, hard coal and lignite are still worldwide strategic raw materials, as indicated by the levels of extraction of these raw materials. In 2014, Poland ranked tenth and fifth among the world's largest producers of hard coal and lignite, respectively (EURACOAL statistics 2019b). The majority of hard coal and lignite extracted in Poland are consumed in power plants and combined heat and power plants (Central Statistical Office 2017, 2018). The energy production by combustion of fossil fuels in power boilers involves the emission of a number of pollutants, which include volatile compounds such as $\mathrm{CO}_{2}, \mathrm{SO}_{2}, \mathrm{NO}_{x}, \mathrm{Hg}^{0}$ or heavy metals and coal combustion products (CCP), such as fly ashes, slags, bottom ashes, gypsum after wet flue gas desulfurization (FGD) (EURACOAL statistics 2019c). A meaningful part of CCP has potential for re-use as an anthropogenic raw material (Antiohos and Tsimas 2007; 
Garcia-lodeiro et al. 2017; Li et al. 2017a; Benassi et al. 2017).

Fly ash, which is the subject of research in this work, is also recognized as one of the most important CCP wastes due to the largest share of them CCP (approx. 65\% according to American Coal Ash Association). According to data of Polish Central Statistical Office (GUS), the production of fly ash (in Poland) between 2014 and 2018 reached 3.8, 3.8, 3.3, 3.4 and 2.8 million tonnes, respectively. It constituted $2.89 \%, 2.52 \%, 2.57 \%, 2.99 \%$ and $2.08 \%$ in the annual general balance of generated waste (excluding municipal waste) (Central Statistical Office 2015, 2016, 2017, 2018, 2019). Considering the new restriction of BREF/BAT, they oblique energy sector to introduce new technologies that can influence of quality and properties of fly ash, disqualifying them for commercial application. For example during failure of $\mathrm{DeNO}_{x}$ installations ammonia slip to fly ash simultaneously exclude its application for concretes or mortars. Also due to unconventional burning of coal a rich-carbon fly ash is obtained what also disqualified it in building applications due to the high value of loss on ignition. It is also know that in case of fly ash C class, percentage of them usage is very low (Van den Berger and Cornelissen 1999; Wdowin 2020).

Due to such large amounts of these wastes, new methods of their application and effective re-use are still being sought. An additional stimulus is the changing of legal regulations regarding waste storage, which are to introduce new restrictions and increase the fees for their storage (Szczygielski 2015).

Due to the still not fully used possibilities offered by material such as fly ash and in accordance with the zero waste idea, the wide range of potential solutions for fly ash management were proposed in recent years. When considering the various benefits of fly ash availability and their physicochemical properties, a number of dangers should also be taken into account. Main danger is strongly associated with chemical composition of fly ashes and the presence of some hazardous elements. Special attention should be paid to heavy metals and threat of their leaching and potential of release into the environment. Depending on the coal type, the average concentration of heavy metals is varied. Hazardous concentrations of arsenic (2.8-6300 ppm), mercury (0.02-0.36 ppm), molybdenium $(1.2-236 \mathrm{ppm})$ and selenium have been reported in fly ashes (Izquierdo and Querol 2012). So far, fly ash has been successfully used, among others: in the green building materials industry (Antiohos and Tsimas 2007; Imbabi et al. 2012; Miranda et al. 2017), as an addition to asphalt (Çelik 2008; Mistry and Roy 2016; Mohammadinia et al. 2017), in civil engineering (Cabrera and Woolley 1994; Sato and Nishimoto 2005; Abdulhalim and Doğruyol 2014;
Kesharwani et al. 2017), in agriculture (Basu et al. 2009; Kishor et al. 2010; Yunusa et al. 2012; Singh and Pandey 2013; Singh et al. 2014; Dahiya and Budania 2018), in mining industry (Ram and Masto 2010; Shang 2016; Jiang et al. 2017). One of the methods of fly ash reuse is their application as a substrate (the main carrier of silicon and aluminum) in the production of aluminosilicate zeolite and other porous materials (Murayama et al. 2002; Querol et al. 2002; Franus et al. 2014; Wdowin et al. 2014a; Czarna et al. 2016; Kunecki et al. 2017, 2018). Considering utilization of fly ashes by using them as main subtracts in the synthesis of zeolites it should also be noted that using strong alkaline medium (the environment of hydrothermal synthesis) leads to the dissolution of many compounds from fly ash. The investigation of heavy metals mobility during zeolite synthesis prove that the zeolitization process leads to the immobilization of hazardous heavy metals within the zeolite structure, despite the fact that some metalloids may migrate to wastewaters occurred after synthesis. In case of raw fly ashes migration of toxic elements was noticed (Feng et al. 2018).

The aim of this work is to evaluate the effect of grinding degree and the chemical class of a number of fly ash on the efficiency of hydrothermal synthesis of zeolites: Na-P1, $\mathrm{Na}-\mathrm{X}, \mathrm{Na}-\mathrm{A}$ and sodalite. Special attention is paid to the factors of grinding degree as well as to the chemical class of a number of fly ash in order to deeper understanding the dependencies affecting nucleation, crystallization and the efficiency of the synthesis of a number of zeolites. The influence of grinding degree of fly ash in zeolitization process was investigated due to the fact that it is know that by grinding process the increase of reactive surface is observed. Therefore such pre-treatment can influence on extent of zeolite crystallization, time of reaction as well as purity and ordering of structure obtained porous materials. The better the structure is developed and the higher purity of zeolite material will be achieved, the more specific zeolite application directions may be potentially available, e.g. catalysts. The authors put forward a hypothesis that the decrease in the size of the fraction of ash used will result in the formation of zeolite phases with a higher purity and crystallinity, which directly affect the improvement of the physicochemical properties of the phases obtained.

\section{Materials and methods}

\subsection{Starting materials and grinding process}

The starting material used as the main substrate (silicon and aluminum carrier) comprised the samples of 6 fly ashes. These fly ashes resulted from the conventional combustion of hard coal and lignite. The hard coal derived 
samples of fly ash are named F1000, F2000, F3000, F4000, F6000 and were taken from electrostatic precipitators installed in the Polish power plants located in Skawina, Siekierki, Jaworzno, Połaniec and Puławy, respectively. The sample F5000 was derived from lignite combustion in power plant Bełchatów. In all power plants except Połaniec (F4000) only coal is subjected to combustion (in Połaniec Power Plant co-combustion of coal and biomass is used, which may result in slightly different results). Each of the analysed fly ashes was subjected to grinding in variable magnetic field and homogenization processes. Using magnetic field grinder for milling of small fraction is an innovative approach. This research involved the use of a magnetic inductor generating induction in the working field at the level of $0.09 \mathrm{~T}$ with the demand for active power at the level of $4 \mathrm{~kW}$. The three-phase inductor of the electromagnetic field is made as an inductor with overt poles. The outer yoke has the shape of a hexagon, the poles are arranged symmetrically and perpendicular to the sides of the hexagon. The windings of opposite poles are connected in parallel and connected to interfacial tension. Generally, the windings are connected in a triangle with the possibility of star connection. The methodology of the F1000 grinding process is presented in the Table 1 below. The next ashes were milled analogously.

As a result, in this experiment a given ash occurred in various grinding stages where e.g.: F1000 means the raw fly ash sample with the lowest grinding degree and F1004 with the highest grinding degree. The raw fly ash sample named F6000 was known to authors from the previous laboratory tests and has been defined as most prospective in terms of the zeolite synthesis. For this reason, the sample has two grinding degrees more than the other fly ashes.

High purity $(>98 \%)$ sodium hydroxide $(\mathrm{NaOH})$ from STANLAB was used as the agent alkalizing the environment of fly ash conversion into zeolite materials. In the case of Na-P1 type zeolite and sodalite syntheses, halite $(\mathrm{NaCl})$ was used to increase the presence of the $\mathrm{Na}^{+}$cations. For the synthesis of Na-A type zeolite, an additional aluminum source in the form of aluminum foil $(>98 \mathrm{wt} \%$ of $\mathrm{Al}$ confirmed by XRF) was used to reduce the $\mathrm{Si} / \mathrm{Al}$ molar ratio.

\subsection{Methods}

\subsubsection{Particle size analysis (PSA)}

PSA was performed in order to diagnose the degree of grinding characterizing the ash samples. The study of the particle size and distribution of the raw and milled fly ash was carried out using the laser particle-size analyser.

\subsubsection{Scanning electron microscopy (SEM)}

SEM was used in order to characterize the morphological properties in micro-area. The morphological forms of the main mineral components were determined by means of the scanning electron microscope equipped with a secondary electron detector.

\subsubsection{Powder $x$-ray diffraction $(X R D)$}

A number of mineralogical analysis were made in order to comprehensively characterize the starting materials and zeolite phases resulted from the hydrothermal synthesis. XRD was used for phase composition analysis. XRD was performed using powder method by X-ray diffractometer with a goniometer and a $\mathrm{Cu}$ lamp, as well as a graphite monochromator. The analysis were performed in the angular $2 \theta$ range of $5^{\circ}-65^{\circ}$. For processing diffraction data, $X^{\prime}$ Pert HighScore Plus software was used.

\subsubsection{X-ray fluorescence spectroscopy $(X R F)$}

XRF was used to determine the qualitative and semiquantitative chemical composition. The XRF analysis was performed by means of energy dispersive X-ray fluorescence spectrometer. The test was carried out in the range of $\mathrm{Na}-\mathrm{Am}$ on an apparatus equipped with an X-ray tube (Rh $9 \mathrm{~V}, 50 \mathrm{kV}, 1 \mathrm{~mA}$ ), a 4096-channel spectrum analyser, six measurement filters $(\mathrm{Cu}-500, \mathrm{Cu}-300, \mathrm{Ti}, \mathrm{Al}-50, \mathrm{Al}-200$,

Table 1 Methodology of grinding process in electromagnetic grinder

\begin{tabular}{lllllll}
\hline $\begin{array}{l}\text { Sample } \\
\text { name }\end{array}$ & $\begin{array}{l}\text { Millner } \\
\text { size }\end{array}$ & $\begin{array}{l}\text { Number of grinding } \\
\text { cycles }\end{array}$ & $\begin{array}{l}\text { Air } \\
\text { ioniser }\end{array}$ & $\begin{array}{l}\text { Sample } \\
\text { mass (kg) }\end{array}$ & $\begin{array}{l}\text { Time of } \\
\text { cycle (min) }\end{array}$ & $\begin{array}{l}\text { Current on the } \\
\text { winding (A) }\end{array}$ \\
\hline F1000 & N/A & N/A & N/A & N/A & N/A & N/A \\
F1001 & Large & 1 & Yes & 0.5 & 45 & 76 \\
F1002 & Large & 2 & & & & \\
F1003 & Small & 1 & & & & \\
F1004 & Small & 2 & & & \\
\hline
\end{tabular}


$\mathrm{Ag}$ ) and an SDD high-resolution semiconductor detector (Be window, with a thickness of $50 \mu \mathrm{m}$ ) cooled by a Peltier cell. It is worthy to note that for XRF method they were prepareinternal standards for $\mathrm{Si}$ and $\mathrm{Al}$ made based on solution determined by ICP method. Thanks to such solution using XRF method it is possible to determine ions that were dissolved.

\subsubsection{Cation exchange capacity (CEC)}

CEC - was determined using the $\mathrm{NH}_{4} \mathrm{Cl}$ method. The $0.5 \mathrm{~g}$ of sample was mixed with $30 \mathrm{~mL}$ of $1 \mathrm{M} \mathrm{NH}_{4} \mathrm{Cl}$. Next, obtained solutions were mixed for $8 \mathrm{~h}$ using magnetic stirrer and heated to the temperature of $60{ }^{\circ} \mathrm{C}$. Afterwards, the mixture was left for $24 \mathrm{~h}$ in order to separate and decant the solutions over precipitates. The procedure was repeated 5 times. Next, using Atomic Adsorption Spectrometer (AAS) instrument, the content of calcium, magnesium, sodium and potassium were measured and the sum of elements contents was calculated to CEC per $100 \mathrm{~g}$ of sample (Franus and Wdowin 2010).

\subsection{Laboratory scale synthesis procedures and products}

The zeolite materials (Na-P1, Na-X, Na-A and sodalite) were synthesized using a simple one-step hydrothermal method. In order to obtain the appropriate zeolite structures, a series of reactions were carried out according to the following procedures:

Na-A: $20 \mathrm{~g} \mathrm{FA}+250 \mathrm{~mL} 3 \mathrm{M} \mathrm{NaOH}+1 \mathrm{~g}$ of aluminum foil (temperature: $95{ }^{\circ} \mathrm{C}$, time: $4 \mathrm{~h}$ )

Na-P1: 20 g FA + $400 \mathrm{~mL} 1 \mathrm{M} \mathrm{NaOH}+100 \mathrm{~mL} 3 \mathrm{M}$

$\mathrm{NaCl}$ (temperature: $105{ }^{\circ} \mathrm{C}$, time: $24 \mathrm{~h}$ )

Na-X: 20 g FA + $500 \mathrm{~mL} 3 \mathrm{M} \mathrm{NaOH}$ (temperature: $80{ }^{\circ} \mathrm{C}$, time: $24 \mathrm{~h}$ )

Sodalite: $20 \mathrm{~g} \mathrm{FA}+400 \mathrm{~mL} 5 \mathrm{M} \mathrm{NaOH}+200 \mathrm{~mL}$

$3 \mathrm{M} \mathrm{NaCl}$ (temperature: $105{ }^{\circ} \mathrm{C}$, time: $24 \mathrm{~h}$ )

For each of the syntheses, the substrates were placed in $1000 \mathrm{~mL}$ polypropylene containers and intensively mixed until complete dissolution of the $\mathrm{NaOH}$ granules. Next, the lids of the containers were covered with aluminum foil and the prepared batches were placed in the oven at the set temperature and time. After the synthesis, the excess $\mathrm{NaOH}$ solution was poured off, the zeolite material was rinsed several times with distilled water and then dried at $105^{\circ} \mathrm{C}$ for $24 \mathrm{~h}$ and re-homogenized. The prepared material was subjected to analyses. Origin of fly ash samples, symbols of grinding degree as well as symbol of given derived zeolites are summarized in Table 2 below.

\section{Results}

\subsection{Characteristics of fly ashes}

\subsubsection{Particle size analysis (PSA)}

Figure 1 below shows the course of granulometric analysis. In the case of fly ash F1000 and its derivatives, the analysis of the granulometric composition clearly indicates that each subsequent sample up to F1004 is characterized by the more significant participation of smaller particles than the previous one. An almost linear relationship is observed. For the samples F1000 to F1004, the characteristic grain diameters Dx(10), Dx(50) and Dx(90) were varied as follows: $\operatorname{Dx}(10)$ : $4.51,2.54,2.20,1.93,1.52 \mu \mathrm{m}$; $\operatorname{Dx}(50)$ : 24.50, 10.40, 10.40, 7.30, $5.81 \mu \mathrm{m}$; Dx(90): 96.9, 42.40, $48.20,28.60,23.60 \mu \mathrm{m}$. In the case of fly ash F2000 and its derivatives, there is an anomaly in the analysis of F2003 sample, which-contrary to expectations-is characterized by a higher proportion of larger particles than the F2001 and F2002 samples. The highest degree of grinding is shown in the F2004 and F2002 samples, respectively. For the F2000 to F2004 samples, the characteristic grain diameters $\mathrm{Dx}(10), \mathrm{Dx}(50)$ and $\mathrm{Dx}(90)$ were varied as follows: $\operatorname{Dx}(10)$ : 7.64, 3.21, 2.78, 4.26, $2.22 \mu \mathrm{m}$; $\operatorname{Dx}(50)$ : 56.20, 17.90, 17.90, 27.90, $12.50 \mu \mathrm{m}$; Dx(90): 205.00, $85.40,90.80,116.00,73.30 \mu \mathrm{m}$. In the case of F3000 fly ash and its derivatives, the same relationship appears as for the F1000 ashes with derivatives. The analysis of the granulometric composition shows an almost linear relationship_each subsequent sample_from F3000 to F3004 is characterized by larger participation of particles with a smaller diameter than the previous one. For the samples F3000 to F3004, the characteristic grain diameters Dx(10), $\operatorname{DX}(50)$ and $\operatorname{Dx}(90)$ were varied as follows: $\operatorname{Dx}(10): 4.53$, 3.86, 3.36, 2.86, $2.29 \mu \mathrm{m}$; $\mathrm{Dx}(50)$ : 46.20, 29.20, 24.70, 17.50, $11.10 \mu \mathrm{m}$; Dx(90): 190.00, 112.00, 110.00, 82.40, $54.40 \mu \mathrm{m}$. In the case of the F4000 fly ash together with the derivatives, an anomaly is observed for the F4001 sample, which is the most similar to the most ground sample, i.e. F4004 in terms of its granulometric characteristic. For the samples F4000 to F4004, the characteristic grain diameters $\operatorname{Dx}(10), \operatorname{Dx}(50)$ and $\operatorname{Dx}(90)$ were varied as follows:Dx(10): 5.11, 2.32, 2.91, 2.62, $1.84 \mu \mathrm{m}$; $\mathrm{Dx}(50): 50.70$, $10.80,21.80,15.20,8.02 \mu \mathrm{m} ; \mathrm{Dx}(90)$ : 223.00, 69.30, $126.00,72.10,37.20 \mu \mathrm{m}$. The case of F5000 ash with derivatives is similar to F1000 and F3000 (including derivatives). By analogy, almost linear dependence is observed here-each successive sample-from F5000 to F5004 is characterized by larger participation of particles with a smaller diameter than the previous one. This indicates an efficiently controlled grinding process for these 
Table 2 Explanations regarding the origin and symbols denoting specific fly ashes, their ground derivatives and the zeolites obtained from them

\begin{tabular}{|c|c|c|c|c|c|c|}
\hline $\begin{array}{l}\text { Origin of FA } \\
\text { (power plant) }\end{array}$ & $\begin{array}{l}\text { Symbol of FA grinding } \\
\text { degree (last digit) }\end{array}$ & $\begin{array}{l}\text { Symbol of derived } \\
\text { Na-A zeolites }\end{array}$ & $\begin{array}{l}\text { Symbol of derived } \\
\text { Na-P1 zeolites }\end{array}$ & $\begin{array}{l}\text { Symbol of derived } \\
\mathrm{Na}-\mathrm{X} \text { zeolites }\end{array}$ & $\begin{array}{l}\text { Symbol of derived } \\
\text { sodalite zeolites }\end{array}$ & $\begin{array}{l}\text { Symbol } \\
\text { on figures }\end{array}$ \\
\hline \multirow[t]{5}{*}{ (F1) Skawina } & F1000 & $1000 \mathrm{Na}-\mathrm{A}$ & $1000 \mathrm{Na}-\mathrm{P} 1$ & $1000 \mathrm{Na}-\mathrm{X}$ & 1000 SOD & A \\
\hline & F1001 & $1001 \mathrm{Na}-\mathrm{A}$ & $1001 \mathrm{Na}-\mathrm{P} 1$ & $1001 \mathrm{Na}-\mathrm{X}$ & 1001 SOD & \\
\hline & F1002 & $1002 \mathrm{Na}-\mathrm{A}$ & $1002 \mathrm{Na}-\mathrm{P} 1$ & $1002 \mathrm{Na}-\mathrm{X}$ & 1002 SOD & \\
\hline & F1003 & $1003 \mathrm{Na}-\mathrm{A}$ & 1003 Na-P1 & $1003 \mathrm{Na}-\mathrm{X}$ & 1003 SOD & \\
\hline & F1004 & $1004 \mathrm{Na}-\mathrm{A}$ & 1004 Na-P1 & $1004 \mathrm{Na}-\mathrm{X}$ & 1004 SOD & \\
\hline \multirow[t]{5}{*}{ (F2) Siekierki } & F2000 & $2000 \mathrm{Na}-\mathrm{A}$ & $2000 \mathrm{Na}-\mathrm{P} 1$ & $2000 \mathrm{Na}-\mathrm{X}$ & 2000 SOD & B \\
\hline & F2001 & $2001 \mathrm{Na}-\mathrm{A}$ & $2001 \mathrm{Na}-\mathrm{P} 1$ & $2001 \mathrm{Na}-\mathrm{X}$ & 2001 SOD & \\
\hline & F2002 & $2002 \mathrm{Na}-\mathrm{A}$ & 2002 Na-P1 & $2002 \mathrm{Na}-\mathrm{X}$ & 2002 SOD & \\
\hline & F2003 & $2003 \mathrm{Na}-\mathrm{A}$ & 2003 Na-P1 & $2003 \mathrm{Na}-\mathrm{X}$ & 2003 SOD & \\
\hline & F2004 & $2004 \mathrm{Na}-\mathrm{A}$ & 2004 Na-P1 & $2004 \mathrm{Na}-\mathrm{X}$ & 2004 SOD & \\
\hline \multirow[t]{5}{*}{ (F3) Jaworzno } & F3000 & $3000 \mathrm{Na}-\mathrm{A}$ & $3000 \mathrm{Na}-\mathrm{P} 1$ & $3000 \mathrm{Na}-\mathrm{X}$ & 3000 SOD & $\mathrm{C}$ \\
\hline & F3001 & $3001 \mathrm{Na}-\mathrm{A}$ & $3001 \mathrm{Na}-\mathrm{P} 1$ & $3001 \mathrm{Na}-\mathrm{X}$ & 3001 SOD & \\
\hline & F3002 & $3002 \mathrm{Na}-\mathrm{A}$ & $3002 \mathrm{Na}-\mathrm{P} 1$ & $3002 \mathrm{Na}-\mathrm{X}$ & 3002 SOD & \\
\hline & $\mathrm{F} 3003$ & $3003 \mathrm{Na}-\mathrm{A}$ & 3003 Na-P1 & $3003 \mathrm{Na}-\mathrm{X}$ & 3003 SOD & \\
\hline & F3004 & $3004 \mathrm{Na}-\mathrm{A}$ & 3004 Na-P1 & $3004 \mathrm{Na}-\mathrm{X}$ & 3004 SOD & \\
\hline \multirow[t]{5}{*}{ (F4) Połaniec } & F4000 & $4000 \mathrm{Na}-\mathrm{A}$ & $4000 \mathrm{Na}-\mathrm{P} 1$ & $4000 \mathrm{Na}-\mathrm{X}$ & 4000 SOD & $\mathrm{D}$ \\
\hline & F4001 & $4001 \mathrm{Na}-\mathrm{A}$ & $4001 \mathrm{Na}-\mathrm{P} 1$ & $4001 \mathrm{Na}-\mathrm{X}$ & 4001 SOD & \\
\hline & $\mathrm{F} 4002$ & $4002 \mathrm{Na}-\mathrm{A}$ & 4002 Na-P1 & $4002 \mathrm{Na}-\mathrm{X}$ & 4002 SOD & \\
\hline & F4003 & $4003 \mathrm{Na}-\mathrm{A}$ & $4003 \mathrm{Na}-\mathrm{P} 1$ & $4003 \mathrm{Na}-\mathrm{X}$ & 4003 SOD & \\
\hline & F4004 & $4004 \mathrm{Na}-\mathrm{A}$ & $4004 \mathrm{Na}-\mathrm{P} 1$ & $4004 \mathrm{Na}-\mathrm{X}$ & 4004 SOD & \\
\hline \multirow[t]{5}{*}{ (F5) Bełchatów } & F5000 & $5000 \mathrm{Na}-\mathrm{A}$ & $5000 \mathrm{Na}-\mathrm{P} 1$ & $5000 \mathrm{Na}-\mathrm{X}$ & 5000 SOD & $\mathrm{E}$ \\
\hline & F5001 & $5001 \mathrm{Na}-\mathrm{A}$ & $5001 \mathrm{Na}-\mathrm{P} 1$ & $5001 \mathrm{Na}-\mathrm{X}$ & $5001 \mathrm{SOD}$ & \\
\hline & F5002 & $5002 \mathrm{Na}-\mathrm{A}$ & $5002 \mathrm{Na}-\mathrm{P} 1$ & $5002 \mathrm{Na}-\mathrm{X}$ & $5002 \mathrm{SOD}$ & \\
\hline & F5003 & $5003 \mathrm{Na}-\mathrm{A}$ & $5003 \mathrm{Na}-\mathrm{P} 1$ & $5003 \mathrm{Na}-\mathrm{X}$ & 5003 SOD & \\
\hline & F5004 & $5004 \mathrm{Na}-\mathrm{A}$ & 5004 Na-P1 & $5004 \mathrm{Na}-\mathrm{X}$ & 5004 SOD & \\
\hline \multirow[t]{7}{*}{ (F6) Puławy } & F6000 & $6000 \mathrm{Na}-\mathrm{A}$ & $6000 \mathrm{Na}-\mathrm{P} 1$ & $6000 \mathrm{Na}-\mathrm{X}$ & 6000 SOD & $\mathrm{F}$ \\
\hline & F6001 & $6001 \mathrm{Na}-\mathrm{A}$ & $6001 \mathrm{Na}-\mathrm{P} 1$ & $6001 \mathrm{Na}-\mathrm{X}$ & $6001 \mathrm{SOD}$ & \\
\hline & F6002 & $6002 \mathrm{Na}-\mathrm{A}$ & 6002 Na-P1 & $6002 \mathrm{Na}-\mathrm{X}$ & 6002 SOD & \\
\hline & F6003 & $6003 \mathrm{Na}-\mathrm{A}$ & 6003 Na-P1 & $6003 \mathrm{Na}-\mathrm{X}$ & 6003 SOD & \\
\hline & F6004 & $6004 \mathrm{Na}-\mathrm{A}$ & 6004 Na-P1 & $6004 \mathrm{Na}-\mathrm{X}$ & 6004 SOD & \\
\hline & F6005 & $6005 \mathrm{Na}-\mathrm{A}$ & 6005 Na-P1 & $6005 \mathrm{Na}-\mathrm{X}$ & 6005 SOD & \\
\hline & F6006 & $6006 \mathrm{Na}-\mathrm{A}$ & $6006 \mathrm{Na}-\mathrm{P} 1$ & $6006 \mathrm{Na}-\mathrm{X}$ & 6006 SOD & \\
\hline
\end{tabular}

three ashes. For the samples F5000-F5004, the characteristic grain diameters $\operatorname{Dx}(10), \operatorname{Dx}(50)$ and $\operatorname{Dx}(90)$ were varied as follows: $\operatorname{Dx}(10)$ : 20.80, 24.40, 9.82, 5.76, $2.84 \mu \mathrm{m}$; Dx(50): 74.20, 78.50, 56.40, 42.90, $22.50 \mu \mathrm{m}$; Dx(90): $163.00,166.00,136.00,113.00,89.70 \mu \mathrm{m}$. The distribution curves are the sharpest in this case. The particle sizes are contained in the narrowest spectrum. The anomalies observed during the analysis of grain size composition are reflected in the results of the syntheses conducted using individual fractions and types of fly ashes. In the case of the F6000 fly ash and its derivatives, the F6002 sample definitely stands out, which, contrary to expectations, is characterized by the largest proportion of small diameter particles. For the samples F6000 to F6006, the characteristic grain diameters $\operatorname{Dx}(10), \operatorname{Dx}(50)$ and $\operatorname{Dx}(90)$ were varied as follows: $\operatorname{Dx}(10): 7.24,4.69,2.13$, 3.64, 2.28, 4.43, $5.09 \mu \mathrm{m}$; Dx(50): 37.9, 28.4, 7.80, 19.00, $11.70,28.20,24.20 \mu \mathrm{m}$; Dx(90): 138.00, 106.00, 39.60, $75.60,54.00,122.00,104 \mu \mathrm{m}$.

\subsubsection{Scanning electron microscopy (SEM)}

The analysis of SEM micrographs of fly ashes is shown in Fig. 2 below. It is in accordance with the results of PSA and shows the effects of the progressive process of grinding the starting material for synthesis. The figure shows one 


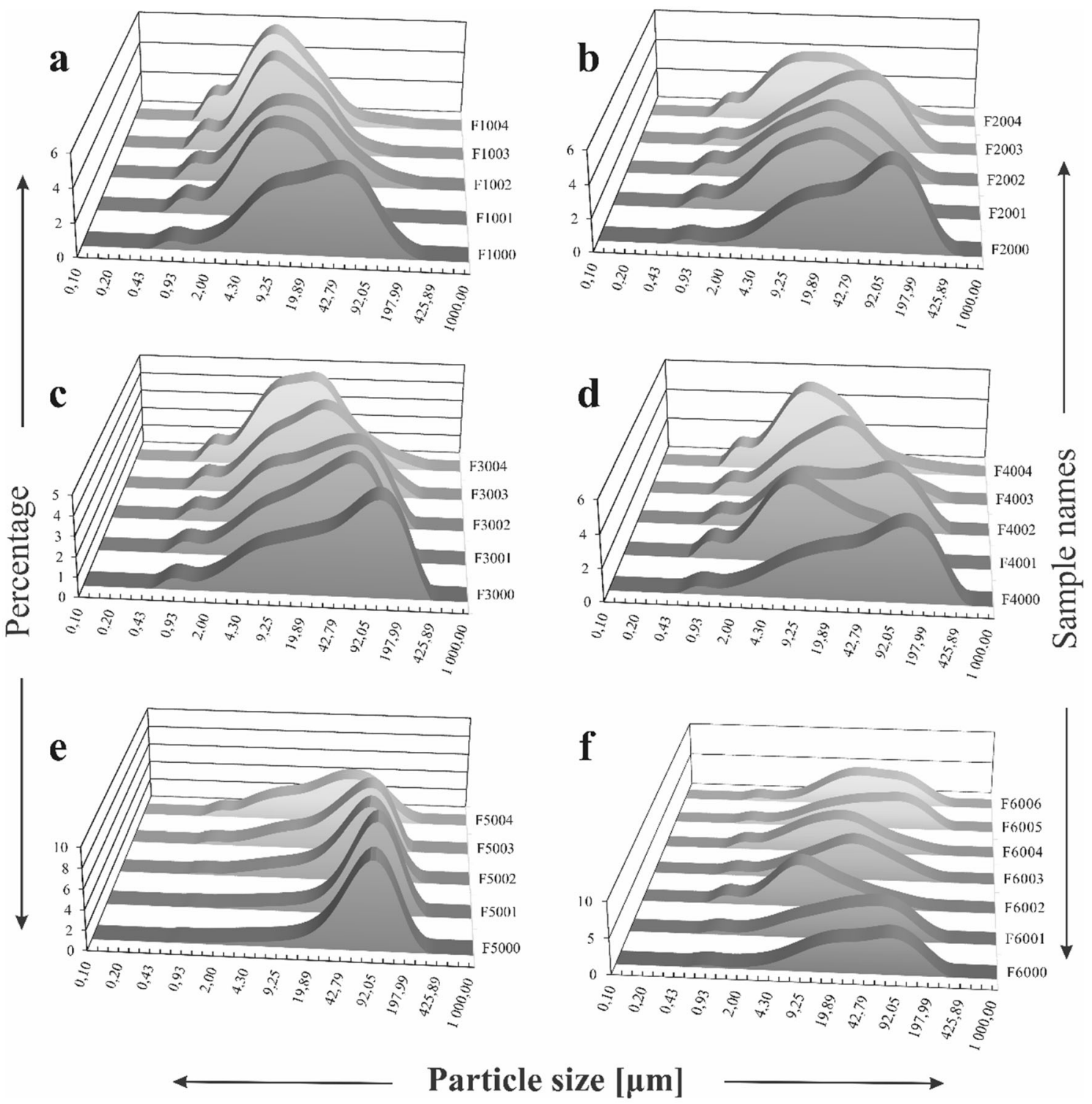

Fig. 1 Particle size analysis of raw fly ashes with their derivatives after grinding process (a FA Skawina, b FA Siekierki, c FA Jaworzno, d FA Połaniec, e FA Bełchatów, f FA Puławy)

SEM image from each fly ash with derivatives after grinding process. In order to objectively show the size of the particles that make up the given ash, one magnification $(4000 \times)$ was selected. There is a visible trend showing the disintegration of spherical and irregular fly ash particles through the grinding process. Fly ash from Power Plant Połaniec (Fig. 2d) showed the highest resistance to the milling process. Probably this is the result of greater share of finer particles in comparison to other fly ashes being investigated. Even in the sample F4004, spherical aluminosilicate enamel particles are still visible. This is probably caused co-combustion of biomass (because only this sample of fly ash has different technology of combustion) where in this case a grains of cenospheres and pleospheres are smaller than in rest of tested fly ashes. Based on the author's experience it is very meaningful from the point of view of zeolite synthesis. Fragmentation of fly ash samples should result in an increase of the reaction surface during dissolution of aluminosilicate glass and, consequently, it should lead to obtaining more material for zeolites crystallization. Increase of reaction surface resulting from milling should provide the synthesis environment with a significant number of new crystallization centers and arouse more intensively nucleation processes. In this case promotion of heterogeneous nucleation is expected-and consequently increase the efficiency of zeolite synthesis including purity and crystallinity level of the final product. 

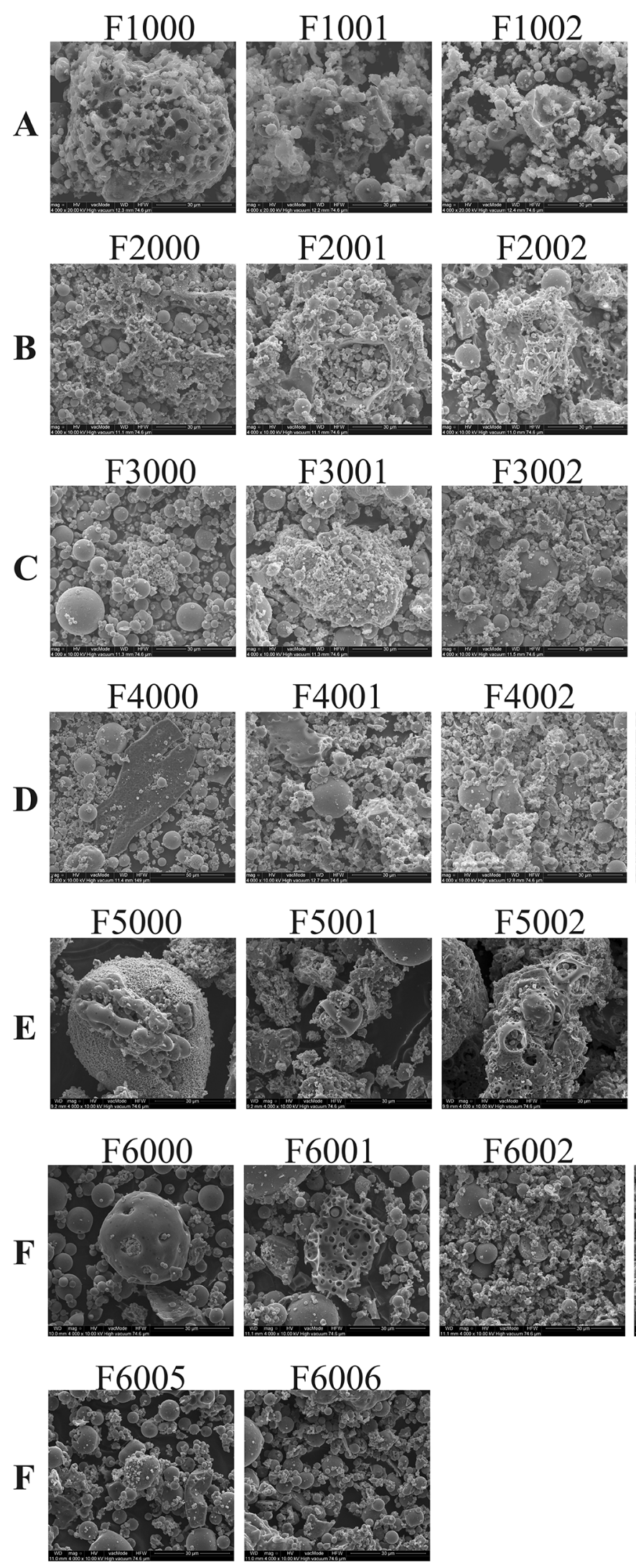
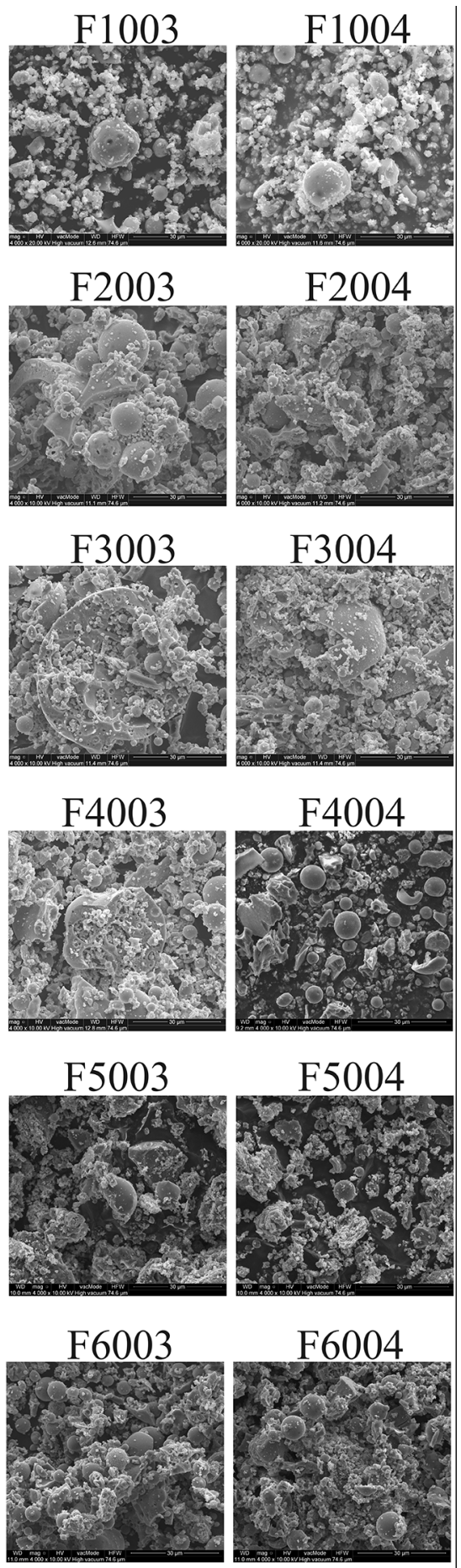

Fig. 2 SEM micrographs of raw fly ashes with their derivatives after grinding process (a FA Skawina, b FA Siekierki, c FA Jaworzno, d FA Połaniec, e FA Bełchatów, f FA Puławy) 

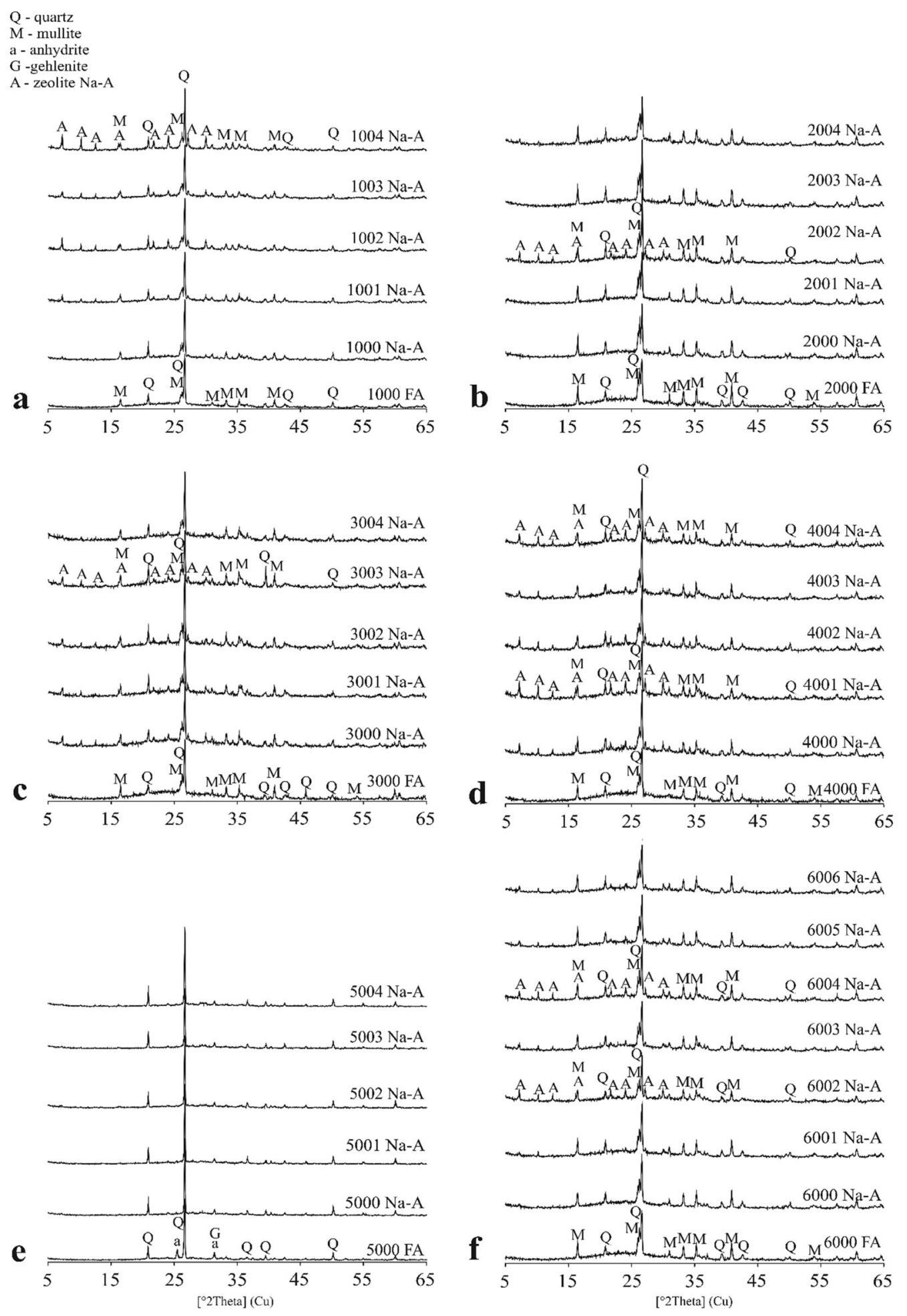

Fig. 3 XRD analyses of raw fly ashes and attempts of Na-A synthesis

\subsubsection{Powder $x$-ray diffraction (XRD)}

The F1000, F2000, F3000, F4000 and F6000 fly ashes possess similar mineralogical properties. Figure 3 shows the phase composition investigation. The following

crystalline phases are present in all indicated samples: mullite $\left(\mathrm{Al}_{6} \mathrm{Si}_{2} \mathrm{O}_{13}\right)$, represented by a set of diffraction peaks with following $d_{\mathrm{hk} 1}$ values: $3.37 ; 3.42 ; 2.20 ; 2.54$; $5.37 ; 1.52 ; 2.68 ; 1.44 ; 2.29 ; 2.89[\AA ̊ \AA]$; quartz $\left(\mathrm{SiO}_{2}\right)$ represented by a set of diffraction peaks with following $d_{\mathrm{hkl}}$ 


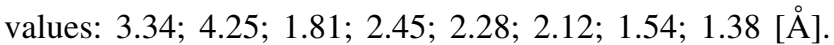
Moreover, the F2000 sample (Fig. 3b) is characterized by the highest degree of mullite crystallinity, which is indicated by the relatively highest intensity of peaks characteristic for this mineral observed on the diffractogram. A similar degree of elevation of the diffractogram background is indirectly indicative of a similar content of amorphous aluminosilicate.

The sample of fly ash marked as F5000 is definitely different from the rest of the analysed ash. In Fig. 3e, quartz was indicated as the main crystalline phase present in the ash. Anhydrite $\left(\mathrm{CaSO}_{4}\right)$ is the next phase characterized with sharp and intense peaks. It is represented by set of diffraction peaks with the following $d_{\mathrm{hkl}}$ values: 3.49 ; $2.85 ; 2.32 ; 2.20[\AA]$. A slight amount of gehlenite $\left(\mathrm{Ca}_{2}\right.$ $\left.\mathrm{Al}(\mathrm{AlSi}) \mathrm{O}_{7}\right)$ was also observed. The much lower background level than in the case of the rest of the analyzed ash indicates a negligible share of amorphous aluminosilicate glass. Already at the level of the initial mineralogical analysis, it indicates that it is a material with much weaker properties in the context of zeolite synthesis because aluminosilicate glass is dissolved the fastest in the basic conversion environment (which is profitable for syntheses of zeolites) providing aluminum and silicon for crystallization of the zeolite phase.

\subsubsection{X-ray fluorescence spectroscopy $(X R F)$}

The analysed fly ashes (F1000, F2000, F3000, F4000 and F6000) also have a similar chemical composition, as shown in Table 3. The amount of aluminum in conversion to $\mathrm{Al}_{2} \mathrm{O}_{3}$ fluctuates in the range from $21.45 \mathrm{wt} \%$ to $24.46 \mathrm{wt} \%$, reaching the lowest value for F4000 and the highest for F2000. The amount of silicon in the form of $\mathrm{SiO}_{2}$ varies between $48.28 \mathrm{wt} \%$ and $53.79 \mathrm{wt} \%$, reaching the lowest value for F4000 and the highest for F6000. Other elements found in fly ash, important from the point of view of zeolite synthesis, also include iron, calcium, sodium, potassium and magnesium (they can act as exchangeable cations in zeolites) (Payra and Dutta 2003). Their content in the form of oxides oscillates between 6.19 wt $\%$ and $8.71 \mathrm{wt} \%$ for $\mathrm{Fe}_{2} \mathrm{O}_{3}$ with the lowest value for F1000 and the highest for F3000, respectively; from 1.64 wt $\%$ to $4.10 \mathrm{wt} \%$ for $\mathrm{CaO}$ with the lowest value for F2000 and the highest for F3000; from $1.96 \mathrm{wt} \%$ to $3.90 \mathrm{wt} \%$ for $\mathrm{Na}_{2} \mathrm{O}$ with the lowest value for $\mathrm{F} 2000$ and the highest for F4000; from $2.63 \mathrm{wt} \%$ to $4.21 \mathrm{wt} \%$ for $\mathrm{K}_{2} \mathrm{O}$ with the

Table 3 Chemical characteristics of raw fly ash samples: F1000, F2000, F3000, F4000, F5000 and F6000 (most important components from zeolite synthesis point of are bolded and italicised)

\begin{tabular}{|c|c|c|c|c|c|c|}
\hline \multirow[t]{2}{*}{ Item } & \multicolumn{6}{|c|}{ Amount (wt\%) } \\
\hline & F1000 & F2000 & F3000 & F4000 & F5000 & F6000 \\
\hline $\mathrm{Na}_{2} \mathrm{O}$ & 2.12 & 1.96 & 2.96 & 3.90 & 1.79 & 2.12 \\
\hline $\mathrm{MgO}$ & 1.64 & 1.10 & 1.96 & 1.39 & 1.22 & 1.21 \\
\hline $\mathbf{A l}_{2} \mathbf{O}_{3}$ & 23.55 & 24.46 & 22.20 & 21.45 & 14.99 & 24.41 \\
\hline $\mathrm{SiO}_{2}$ & 52.54 & 50.42 & 48.78 & 48.28 & 45.59 & 53.79 \\
\hline $\mathrm{P}_{2} \mathrm{O}_{5}$ & 0.91 & 1.35 & 0.86 & 1.37 & 0.54 & 1.40 \\
\hline $\mathrm{SO}_{3}$ & 0.74 & 0.85 & 1.02 & 0.85 & 6.31 & 0.43 \\
\hline $\mathrm{K}_{2} \mathrm{O}$ & 3.48 & 3.06 & 3.31 & 4.21 & 0.22 & 2.63 \\
\hline $\mathrm{CaO}$ & 2.56 & 1.64 & 4.10 & 4.03 & 19.14 & 2.41 \\
\hline $\mathrm{TiO}_{2}$ & 1.28 & 1.58 & 1.24 & 1.60 & 1.83 & 1.47 \\
\hline $\mathrm{Cr}_{2} \mathrm{O}_{3}$ & 0.03 & 0.04 & 0.03 & 0.04 & 0.03 & 0.04 \\
\hline $\mathrm{MnO}$ & 0.08 & 0.04 & 0.08 & 0.09 & 0.03 & 0.04 \\
\hline $\mathrm{Fe}_{2} \mathrm{O}_{3}$ & 6.19 & 6.20 & 8.71 & 8.39 & 5.70 & 7.02 \\
\hline $\mathrm{NiO}$ & 0.02 & 0.03 & 0.02 & 0.03 & 0.01 & 0.03 \\
\hline $\mathrm{CuO}$ & 0.02 & 0.02 & 0.02 & 0.03 & 0.01 & 0.02 \\
\hline $\mathrm{ZnO}$ & 0.02 & 0.02 & 0.05 & 0.04 & 0.02 & 0.02 \\
\hline $\mathrm{BaO}$ & 0.07 & 0.07 & 0.07 & 0.11 & 0.02 & 0.09 \\
\hline LOI & 4.67 & 7.16 & 4.50 & 4.14 & 2.51 & 2.82 \\
\hline$\Sigma$ & 99.91 & 100.00 & 99.91 & 99.92 & 99.97 & 99.94 \\
\hline$\Sigma\left(\mathrm{SiO}_{2}+\mathrm{Al}_{2} \mathrm{O}_{3}+\mathrm{Fe}_{2} \mathrm{O}_{3}\right)$ & 82.28 & 81.08 & 79.68 & 78.11 & 66.29 & 85.22 \\
\hline FA Class & $\mathbf{F}$ & $\mathbf{F}$ & $\mathbf{F}$ & $\mathbf{F}$ & $\mathbf{C}$ & $\mathbf{F}$ \\
\hline
\end{tabular}


lowest value for F6000 and the highest for F4000; and from $1.10 \mathrm{wt} \%$ to $1.96 \mathrm{wt} \%$ for $\mathrm{MgO}$ with the lowest value for F2000 and the highest for F3000. Loss of Ignition (LOI) ranges from $2.82 \mathrm{wt} \%$ to $7.16 \mathrm{wt} \%$ showing the likely variation in the content of unburned carbonaceous matter. The lowest value of LOI was noted for F6000 and the highest for F2000. On the basis of the chemical composition and the American standard ASTM C 618-89 (ASTM International 2015), the indicated ashes were subjected to classification. Reaching the sum $\left(\mathrm{SiO}_{2}+\mathrm{Al}_{2} \mathrm{O}_{3}+\mathrm{Fe}_{2} \mathrm{O}_{3}\right)$ above $70 \mathrm{wt} \%$, the F1000, F2000, F3000, F4000 and F6000 samples are classified as class F fly ash.

The chemical composition of F5000 sample meaningfully stands out from the samples described above (Table 3). The content of the main elements building the zeolite phases-silicon and aluminum, calculated as oxides, is $45.59 \mathrm{wt} \%$ and $14.99 \mathrm{wt} \%$, respectively. These are the lowest values among all analysed fly ashes. This sample, compared to the rest of the ash, also has the lowest content of iron, sodium and potassium, calculated as oxides of $5.70 \mathrm{wt} \%, 1.79 \mathrm{wt} \%$ and $0.22 \mathrm{wt} \%$. The content of magnesium oxide is $1.22 \mathrm{wt} \%$. The F5000 sample is also characterized by a high content of calcium and sulphur; in the form of $\mathrm{CaO}$ and $\mathrm{SO}_{3}$, it reaches $19.14 \mathrm{wt} \%$ and $6.31 \mathrm{wt} \%$, respectively. This result corresponds to the indicated presence of anhydrite and gehlenite. The LOI amounted to $2.51 \mathrm{wt} \%$ which is also the lowest result among the tested ashes. This indicates a negligible contribution of unburned carbonaceous material. On the basis of the chemical composition and the American standard ASTM C 618-89, the indicated ash was subjected to classification. Reaching the sum $\left(\mathrm{SiO}_{2}+\mathrm{Al}_{2} \mathrm{O}_{3}+\mathrm{Fe}_{2} \mathrm{O}_{3}\right.$ equal to $66.29 \mathrm{wt} \%$ ) in the range $50 \mathrm{wt} \%-70 \mathrm{wt} \%$

Table 4 CEC values for raw FA samples and derivatives after grinding

\begin{tabular}{lc}
\hline Sample name & CEC value $(\mathrm{mval} / 100 \mathrm{~g})$ \\
\hline F1000 & 18.93 \\
F1004 & 6.28 \\
F2000 & 13.54 \\
F2004 & 10.43 \\
F3000 & 19.10 \\
F3004 & 10.85 \\
F4000 & 15.47 \\
F4004 & 8.90 \\
F5000 & 18.15 \\
F5004 & 15.79 \\
F6000 & 15.95 \\
F6006 & 11.96 \\
\hline
\end{tabular}

and $>10 \mathrm{wt} \%$ of $\mathrm{CaO}$, the indicated sample was classified as class $\mathrm{C}$ fly ash.

\subsubsection{Cation exchange capacity (CEC)}

For each initial ash and its derivative with the highest degree of grinding, the calculations of cation exchange properties were made. Results are presented in Table 4 below. The milling process affected the decrease of the cation exchange properties of raw fly ash.

\subsection{Laboratory scale synthesis of zeolite phases and their investigation}

\subsubsection{Powder X-ray diffraction (XRD)}

Figures 3, 4, 5 and 6 below present the results of phase composition analysis of initial fly ashes and zeolite phases together with the residues resulting from hydrothermal syntheses. The main substrate was fly ash with varying grinding degree. In the figures, the corresponding letters describe diffractograms characterized by the highest intensity of peaks, indicating the best synthesis results.

The phase analysis of the materials collected after Na-A zeolite synthesis from all fly ashes and their individual fractions is shown in Fig. 3 below. In each case where class F fly ash was used, the influence the fraction of fly ash used on the efficiency of the synthesis is observed. Only in the case of the synthesis using the F5000 fly ash and its derivatives after grinding, zeolite was not obtained.

In the case of the F1000 fly ash with its derivatives after grinding, the Na-A zeolite was obtained in each trial, with the best result obtained for the $1004 \mathrm{Na}-\mathrm{A}$ sample (Fig. 3a).

In analogous trials for the fly ash F2000 together with its ground derivatives, the $\mathrm{Na}-\mathrm{A}$ zeolite was obtained only for syntheses marked as $2004 \mathrm{Na}-\mathrm{A}$ and $2002 \mathrm{Na}-\mathrm{A}$, which was the best result (Fig. 3b).

In the case of the F3000 fly ash with its derivatives after grinding, the Na-A zeolite was obtained in the samples from $3000 \mathrm{Na}-\mathrm{A}$ to $3003 \mathrm{Na}-\mathrm{A}$. The synthesis of $3003 \mathrm{Na}$ A gave the best result. Contrary to the preliminary expectations, Na-A zeolite was not obtained in the synthesis of 3004 (Fig. 3c).

In the case of F4000 ash together with derivatives, the $\mathrm{Na}-\mathrm{A}$ phase was obtained in all samples. The best results was achieved in the syntheses of $4004 \mathrm{Na}-\mathrm{A}$ and $4001 \mathrm{Na}-$ A (the best result). The best results were obtained on ash samples, which were characterized by the highest degree of grinding (description of granulometric analysis above) (Fig. 3d).

As a result of syntheses carried out using F5000 fly ash, the Na-A zeolite was not obtained. Only the disappearance 

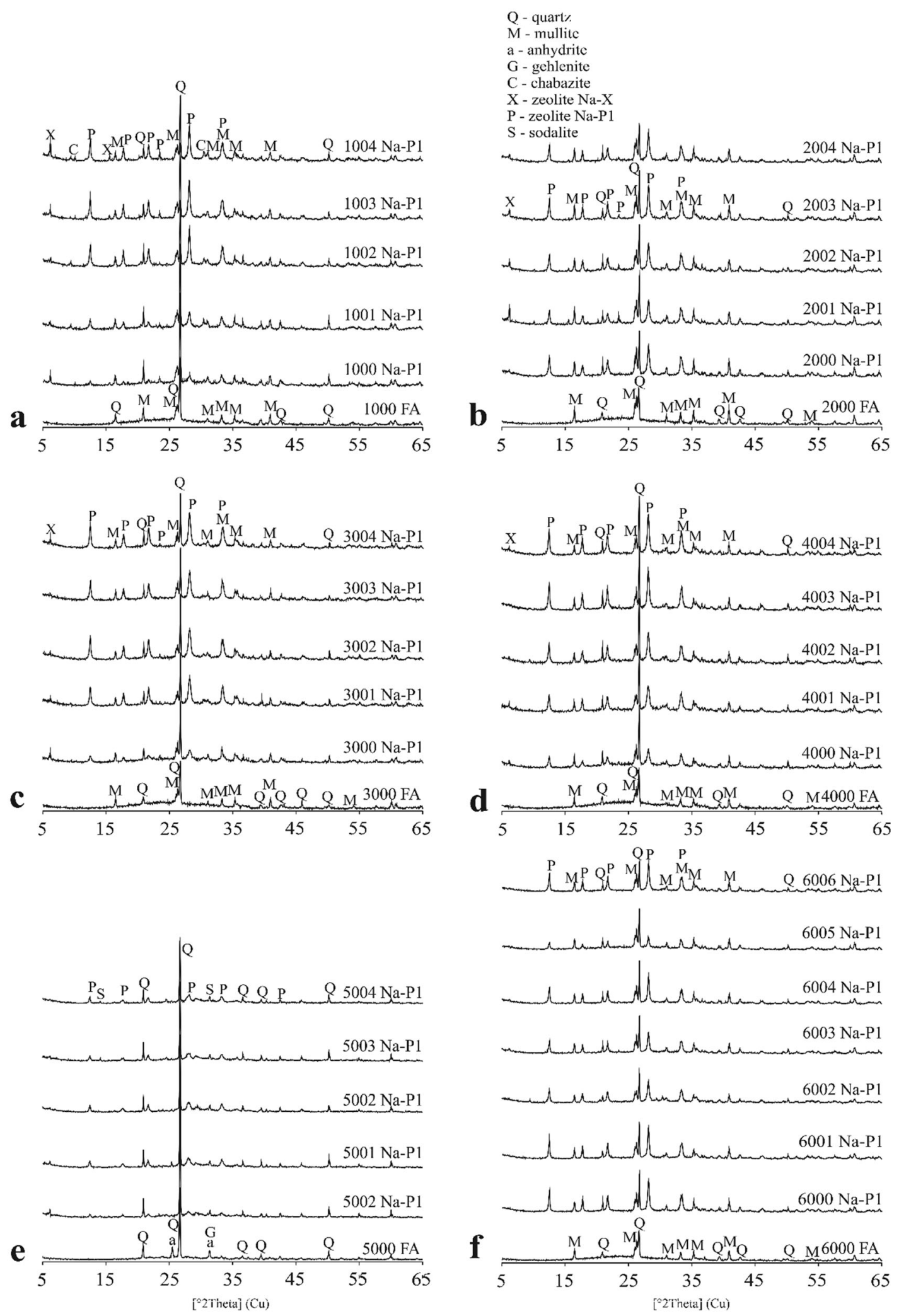

Fig. 4 XRD analyses of raw fly ashes and attempts of Na-P1 synthesis 


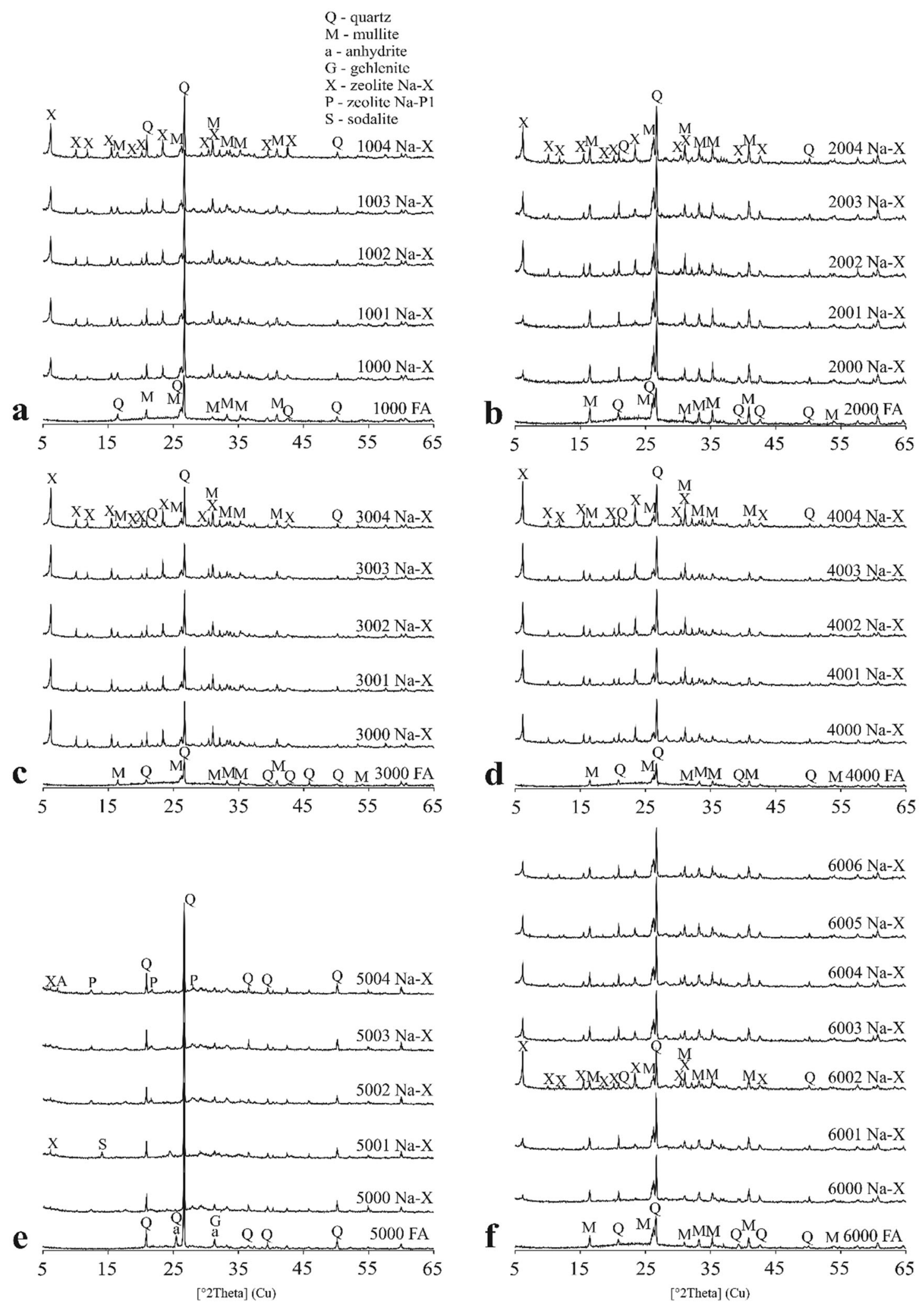

Fig. 5 XRD analyses of raw fly ashes and attempts of $\mathrm{Na}-\mathrm{X}$ synthesis 


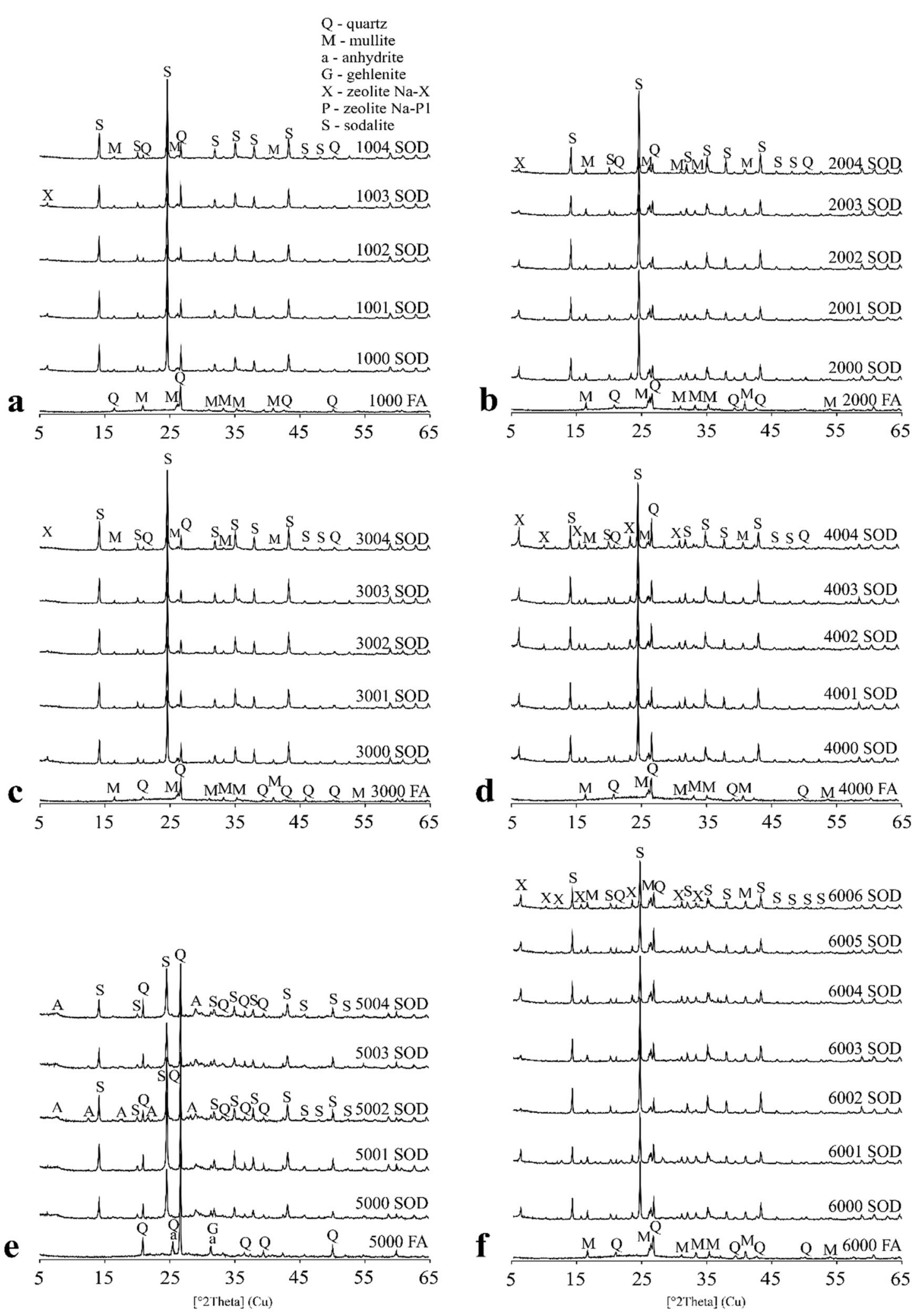

Fig. 6 XRD analyses of raw fly ashes and attempts of sodalite synthesis 
of the characteristic diffraction peaks of anhydrite and reduction of the intensity of the characteristic gehlenite peaks were observed, which indicates the disintegration of these phases during the synthesis (Fig. 3e).

In the case of the F6000 ash together with the grinding derivatives, the $\mathrm{Na}-\mathrm{A}$ phase was obtained in whole set of syntheses from $6001 \mathrm{Na}-\mathrm{A}$ to $6006 \mathrm{Na}-\mathrm{A}$. The best results were obtained for the syntheses of $6002 \mathrm{Na}-\mathrm{A}$ and 6004 $\mathrm{Na}-\mathrm{A}$ (the best result). It is worth noting that the F6002 fly ash was characterized by the largest proportion of small diameter particles (description of granulometric analysis above) (Fig. 3f).

In all attempts indicated as the best results for the selected group of fly ashes, the presence of $\mathrm{Na}-\mathrm{A}$ zeolite phase was diagnosed. The Na-A zeolite is represented by set of characteristic diffraction peaks with $d_{\mathrm{hkl}}$ values: 12.30 (100); 870 (54.1); 7.10 (25.4); 5.50 (17.8); 3.71 (46.3); 3.28 (43.3) 2.98 (47.6); 2.62 (34.6) (in parenthesis the relative intensity of the peaks). In the case of syntheses using Class $\mathrm{F}$ ashes, a residue was also observed in the form of unreacted quartz and mullite. Along with the decrease of the ash fraction used in the synthesis, the trend of reducing the diffraction background on the diffraction patterns of the obtained materials is also observed. This demonstrates the increase in the dissolution efficiency of aluminosilicate glass, which is influenced by the size of fly ash particles.

The phase analysis of materials collected after the Na-P1 zeolite synthesis from all fly ashes and their individual fractions is shown in Fig. 4 below. In the case of the attempts to obtain Na-P1 zeolite in each synthesis using class $\mathrm{F}$ and $\mathrm{C}$ ashes, the influence of the fraction of fly ash used on the efficiency of the synthesis is observed.

In the case of use of F1000 fly ash with its derivatives after grinding, the Na-P1 zeolite was obtained in each trial, the best result achieved for the 1004 Na-P1 sample, where the smallest fraction of fly ash was observed. The majority of samples also indicated the $\mathrm{Na}-\mathrm{X}$ zeolite occurrence (Fig. 4a).

In analogous attempts for the F2000 fly ash together with its grinding derivatives, the Na-P1 zeolite was also obtained in all materials after synthesis. The $2003 \mathrm{Na}-\mathrm{P} 1$ trial gave the best results. Additionally, in this case, the Na$\mathrm{X}$ zeolite was observed in all synthesis attempts (Fig. 4b).

For the F3000 ash with derivatives, as in the previous two cases, the Na-P1 zeolite was obtained in all samples, and the presence of the $\mathrm{Na}-\mathrm{X}$ zeolite was identified as well. A trend of the increase in the intensity of the characteristic peaks of the Na-P1 zeolite was observed along with the decrease of the fractions used in the synthesis of ashes. The synthesis of $3004 \mathrm{Na}-\mathrm{P} 1$ gave the best result (Fig. 4c).

In the case of the use of F4000 ash together with derivatives, the Na-P1 phase was also obtained in all samples. The best results were obtained in the $4004 \mathrm{Na}-\mathrm{P} 1$ trial. Moreover, in this case, the trend of increasing the degree of crystallinity of the phases obtained along with the decrease in the fraction of fly ash used is evident. Each subsequent synthesis is characterized by sharper and higher peaks characteristic of the Na-P1 phase. An accessory Na$\mathrm{X}$ is also visible in all samples (Fig. 4d).

As a result of the syntheses carried out using the F5000 fly ash together with derivatives, the Na-P1 zeolite with a low degree of crystallinity was obtained. The presence of the sodalite zeolite was also diagnosed. The disappearance of the characteristic anhydrite peaks and the reduction in the intensity of the characteristic gehlenite peaks was also observed, which indicates the disintegration of these phases during the synthesis test, as was the case with the Na-A zeolite synthesis attempts (Fig. 4e).

In the case of using F6000 ash together with the derivatives, the Na-P1 phase was obtained for all tests. The best results were obtained for the synthesis of $6006 \mathrm{Na}-\mathrm{P} 1$. This is the only case of using class F ash for the Na-P1 synthesis where the Na-X phase was not obtained (Fig. 4f).

In all attempts indicated as the best results for the selected group of fly ashes, the presence of Na-P1 zeolite phase was observed. Na-P1 zeolite is represented by set of characteristic diffraction peaks with $d_{\mathrm{hkl}}$ values: 7.07 (80); 4.99 (60); 4.08 (80); 3.15 (100); 2.88 (50); 2.66 (80). In the case of the syntheses using Class $\mathrm{F}$ ashes, a residue in the form of unreacted quartz and mullite was also observed, whereas for the Class $\mathrm{C}$ ash in the residue only quartz was found. As the ash fraction decreases, the trend of reducing of diffraction background in the samples after synthesis is also observed. This demonstrates the increase in the dissolution efficiency of aluminosilicate glass, which is influenced by the size of fly ash particles.

The phase analysis of the materials collected after the $\mathrm{Na}-\mathrm{X}$ zeolite synthesis from all fly ashes and their individual fractions is shown in Fig. 5 below. In the case of the attempts to obtain the $\mathrm{Na}-\mathrm{X}$ zeolite in each synthesis using class $\mathrm{F}$ and $\mathrm{C}$ ashes, the influence of the fraction of fly ash used on the efficiency of the synthesis is observed.

When using the F1000 fly ash with its derivatives after grinding, the Na-X zeolite was obtained in each attempt. As before, the best result was achieved by the sample characterized with the smallest ash fraction, described as $1004 \mathrm{Na}-\mathrm{X}$. The trend of increasing degree of crystallinity of the phases obtained along with the decrease of the ash fraction can be clearly observed (Fig. 5a).

In analogous attempts for the F2000 fly ash together with its grinding derivatives, the $\mathrm{Na}-\mathrm{X}$ zeolite was also obtained in all materials after synthesis. As in the case of the F1000 ash, the best result was obtained for the sample where the share of smallest fraction is most significant, named as $2004 \mathrm{Na}-\mathrm{X}$. Similarly as before, the trend of 
increasing degree of crystallinity of the phases obtained along with the decrease of the ash fraction is observed (Fig. 5b).

A very similar situation is observed for the F3000 ash with its grinding derivatives. As in the previous two cases, the Na-X zeolite was obtained in all synthesis attempts. There was also a growing trend pertaining to the intensity of the characteristic Na-X zeolite peaks together with the decrease of the fly ashes fractions used in the synthesis. The trend is slightly less visible in this case as the Na-X zeolites were obtained with a significant degree of crystallinity in all samples. The synthesis of $\mathrm{X}$ type structure in the case of the 3004 sample of fly ash gave the best result (Fig. 5c).

In the case of the F4000 fly ash together with its grinding derivatives, the $\mathrm{Na}-\mathrm{X}$ phase was also obtained in all samples. The best results were obtained in the $4004 \mathrm{Na}$ $\mathrm{X}$ synthesis. Moreover, in this case, the trend of the crystallinity increase of the phases obtained along with the decrease in fraction of fly ash used is evident. Each subsequent synthesis is characterized by sharper and higher peaks characteristic for the Na-X phase. The resulting diffractograms almost reproduce the synthesis results for the F1000 ash together with the derivatives after grinding (Fig. 5d).

As a result of the syntheses conducted using the F5000 fly ash together with its grinding derivatives, the $\mathrm{Na}-\mathrm{X}$ zeolite with very low degree of crystallinity was obtained. In the $5001 \mathrm{Na}-\mathrm{X}$ synthesis attempt, the presence of sodalite zeolite was also identified, while the $5004 \mathrm{Na}-\mathrm{X}$ sample contained small Na-P1 zeolite peaks. The disappearance of the characteristic anhydrite peaks and the reduction in the intensity of the characteristic gehlenite peaks was also observed, which indicates the disintegration of these phases during the synthesis, as was in the case with previous Na-A and Na-P1 syntheses (Fig. 5e).

In the case of synthesis attempts, using the F6000 fly ash together with its grinding derivatives, the $\mathrm{Na}-\mathrm{X}$ phase was obtained for all tests. The best results were obtained for the $6002 \mathrm{Na}-\mathrm{X}$ synthesis, which definitely stands out from the rest of Na-X zeolite synthesis attempts based on the F6000 ashes. The F6002 fly ash used was characterized by the highest degree of grinding according to the PSA analysis (Fig. 5f).

In all attempts indicated as the best results for selected group of fly ashes, the presence of the $\mathrm{Na}-\mathrm{X}$ zeolite phase was confirmed. The Na-X zeolite is represented by set of characteristic diffraction peaks with $d_{\mathrm{hkl}}$ values: 14.47 (100); 8.85 (18); 7.54 (12); 5.73 (18); 3.80 (21); 2.88 (19). In the case of the syntheses using Class $\mathrm{F}$ ashes, a residue in the form of unreacted quartz and mullite was also observed, whereas for the Class $\mathrm{C}$ ash in the residue only quartz was found. As the ash fraction decreases, the trend of reducing of diffraction background in samples after synthesis is observed as well. This demonstrates the increase in the dissolution efficiency of aluminosilicate glass, which is influenced by the size of fly ash particles.

The phase analysis of materials taken after the attempt of synthesis of the sodalite zeolite from all fly ashes and their individual fractions is presented in the following Fig. 6. In the case of the attempts to obtain the sodalite zeolite in each synthesis using class $\mathrm{F}$ and $\mathrm{C}$ fly ashes, the influence of the fraction of fly ash used on the efficiency of the synthesis is observed.

In the case of F1000 with its derivatives after grinding, sodalite was obtained in each attempt, and as in all previous tests, the best result was obtained for the synthesis where the participation of smallest ash fraction was most significant (1004 SOD sample). Moreover, in this case, the trend of increasing the degree of crystallinity of the phases obtained along with the decrease of the ash fraction is clearly observed. In the tests from 1000 SOD to 1003 SOD, the Na-X zeolite is also present in a negligible amount (Fig. 6a).

In analogous synthesis attempts, using the F2000 fly ash with derivatives, sodalite was also obtained in all materials after synthesis. As in the case of the F1000 ash, the best result was obtained for the synthesis 2004 SOD where the smallest ash fraction was used. As before, the trend of increasing degree of crystallinity of the phases obtained along with the decrease of the ash fraction is observed. All samples were also characterized with $\mathrm{Na}-\mathrm{X}$ zeolite occurrence (Fig. 6b).

For the F3000 fly ash with derivatives, as in the previous two cases, sodalite was obtained in all samples. A trend of increasing the intensity of the characteristic peaks of sodalite along with the decrease of ash fractions used in the synthesis was observed as well. The synthesis of 3004 SOD gave the best result. This is the only case where sodalite is the sole zeolite obtained in all samples (Fig. 6c).

In the case of the F4000 ash together with its grinding derivatives, sodalite was also obtained in all samples. The best results were obtained in the synthesis of 4004 SOD. A trend of increasing the intensity of the characteristic peaks of sodalite along with the decrease of ash fractions used in the synthesis was observed (Fig. 6d).

As a result of the syntheses conducted using F5000 fly ash, along with derivatives, sodalite was obtained with a good degree of crystallinity. It is the only zeolite that was produced as a result of the hydrothermal conversion of fly ash class $\mathrm{C}$ in a recognizable and well-shaped form. The best result was obtained for the 5002 SOD sample. In the 5002 SOD and 5004 SOD samples, very small peaks characteristic for the Na-A zeolite were also identified. The disappearance of the characteristic anhydrite peaks and reduction of the intensity of the characteristic gehlenite 
peaks was also observed, which indicates the disintegration of these phases during the synthesis test, as was the case with previous $\mathrm{Na}-\mathrm{A}$ and $\mathrm{Na}-\mathrm{P} 1$ and $\mathrm{Na}-\mathrm{X}$ syntheses (Fig. 6e).

For the F6000 fly ash with its grinding derivatives, sodalite was obtained in all samples. The strongest sodalite peaks are observed in the 6006 SOD sample. As an accompanying phase, the Na-X zeolite was identified, which occurs in all samples except 6002 SOD (Fig. 6f).

In all attempts indicated as the best results for selected group of fly ashes, the presence of sodalite zeolite phase was confirmed. Sodalite is represented by set of characteristic diffraction peaks with $d_{\mathrm{hkl}}$ values: 6.33 (43.1); 3.65 (100); 2.58 (17); 2.39 (14.1); 2.11 (24.9). In the case of the syntheses using Class $\mathrm{F}$ fly ashes, a residue in the form of unreacted quartz and mullite was also observed, whereas for the Class C fly ash in the residue only quartz was found. As the ash fraction decreases, the trend of reducing of diffraction background in samples after synthesis is also observed. This demonstrates the increase in the dissolution efficiency of aluminosilicate glass, which is influenced by the size of fly ash particles.

\subsubsection{Scanning electron microscopy (SEM)}

Figure 7 below shows the SEM micrographs of the samples that gave the best results for the synthesis of a given type of zeolites. In the Na-A zeolite synthesis, $1004 \mathrm{Na}-\mathrm{A}$ samples were the best results. The SEM images show well-formed, cubic LTA type zeolite crystallites with side lengths up to approx. $3 \mu \mathrm{m}$. Some individual crystals reveal overgrowth. In addition to the zeolite phases, residuum in the form of unreacted aluminosilicate glass is visible.

During the Na-P1 zeolite synthesis trials, the best results were obtained for the $6006 \mathrm{Na}$-P1 sample. The Na-P1 zeolite crystallites grow on the surface of fly ash particles. Zeolite creates rosette forms that reach sizes up to approx. 5-6 $\mu \mathrm{m}$. This observation indirectly indicates the heterophasic mechanism of nucleation and crystallization of zeolite.

In the case of the Na-X zeolite synthesis, the $3004 \mathrm{Na}-\mathrm{X}$ sample gave the best result. The crystallites of this phase form quite irregular, sharp-edged forms. They partially build up on the remains of unreacted aluminosilicate glass, partly form separate crystals.

The best result among the synthesis of sodalite was obtained for the 3004 SOD test. Well-formed zeolite needle crystals of approximately $1 \mu \mathrm{m}$ are visible on the SEM images. Crystal forms spherical clusters with a diameter of up to $2-3 \mu \mathrm{m}$, growing on the surface of fly ash particles. Additionally, in this case, this observation indirectly indicates the heterophasic mechanism of nucleation and crystallization of zeolite.

\section{Short overview of potential application for coal fly ash derived zeolites}

According to the results described in this article, the dependence for fly ash grinding as a sufficient way of substrate preparation before zeolite synthesis is clear. The grinding process was performed in order to reduce fraction of substrates and in consequence led to increase the surface of aluminosillicate dissolution reaction. Progressive grinding degree of substrates led to obtaining zeolites with higher degree of crystallinity and purity. This phenomenon may be explained by providing more aluminum and silicon to the reaction solution through the increased surface of the aluminosillicate glass dissolution reaction. Silicon and aluminum are the main elements that create tetrahedronsPrimary Building Units of zeolites and their amount in reaction solution directly affect the effectivity of synthesis. In the literature, no work describing the attempt to improve the efficiency of fly ash derived zeolite syntheses through ash grinding has been presented so far. After deep insight into the XRD results, it may be stated that the most positive response for fly ash grinding is observed in set of Na-P1 and $\mathrm{X}$ structures syntheses. On the basis of the tests carried out, it can be concluded that grinding the substrate in the form of fly ash may bring the best results in the syntheses of GIS (Gismondine) and FAU (Faujasite) type zeolites. These structures, owing to a number of properties, have been widely used for years.

According to a whole set of attractive and useful cation exchange, catalytic, molecular sieves, sorption properties for many years, new applications and new directions of utilization have been sought for zeolites. Among the most important directions of the application, the following can be indicated as most interesting: as addition in asphalt production (Sengoz et al. 2013; Topal et al. 2014; Woszuk and Franus 2016, 2017; Woszuk et al. 2017; Woszuk 2018), civil engineering (Feng and Peng 2005; Tanijaya and Jardjito 2008; Markiv et al. 2016; Linek et al. 2018), in agriculture (Shi et al. 2009; Ramesh and Reddy 2011; Eprikashvili et al. 2016; Behzadfar et al. 2017; Nakhli et al. 2017), in detergent production (Van Dalen and Vooijs 2000; Sekhon and Sangha 2008; Fruijtier-Pölloth 2009; Ayele et al. 2016), in medicine and pharmacy (among other as potential drug carriers) (Andronikashvili et al. 2009; Pavelić and Hadzija 2010; Selvam et al. 2014; Mohammadkhani et al. 2016; Backova et al. 2018; Kraljević Pavelić et al. 2018; Krajišnik et al. 2019), environmental protection and engineering (Maèala et al. 2009; Wdowin et al. 2014b; Burmańczuk et al. 2015; Franus et al. 2015; Ates and Akgül 2016; Czarna et al. 2016), in cosmetology (Joughehdoust and Manafi 2008), in food industry (Kuley et al. 2012), in catalysis (Yilmaz and Müller 2009; 

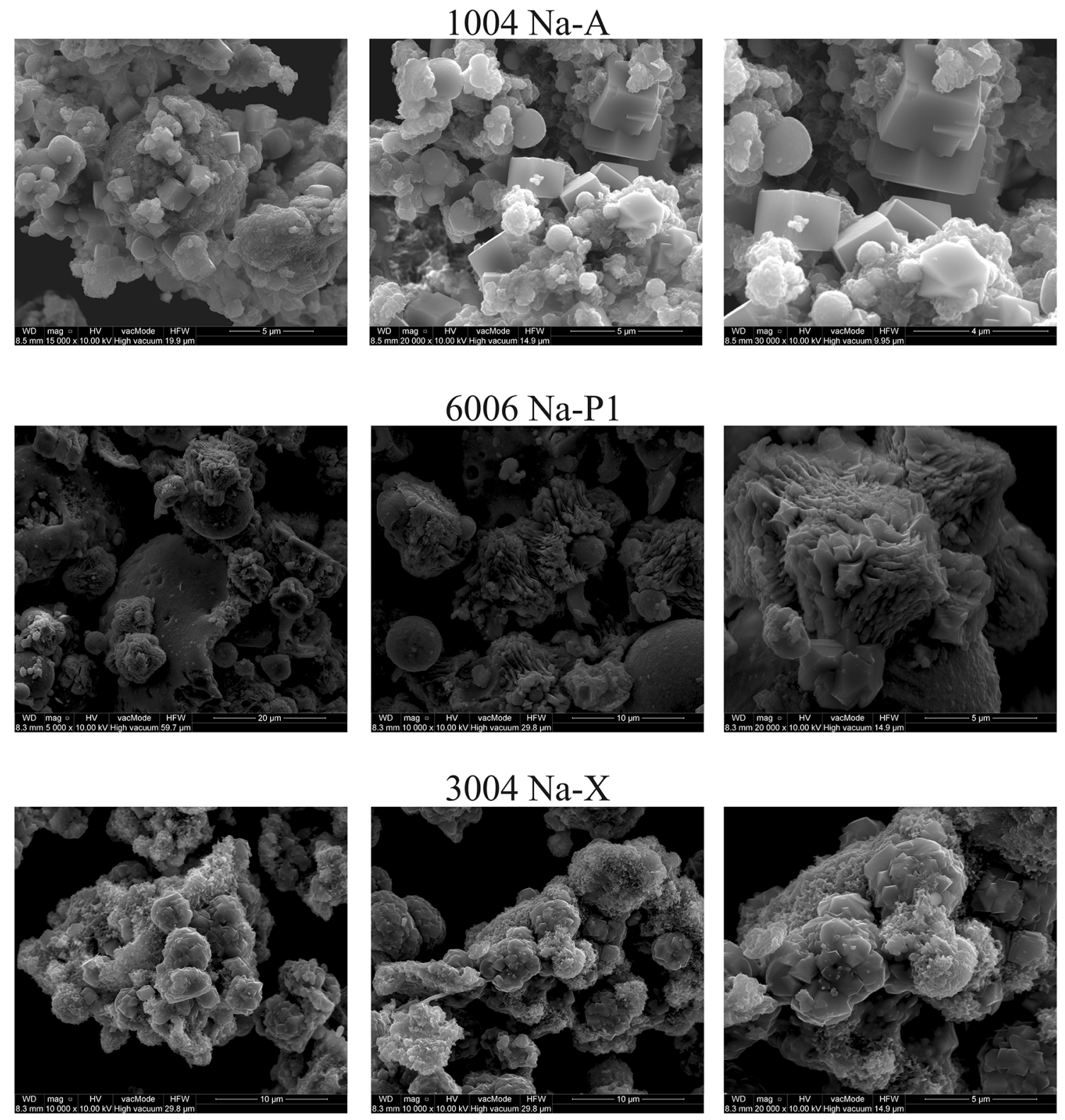

\section{SOD}
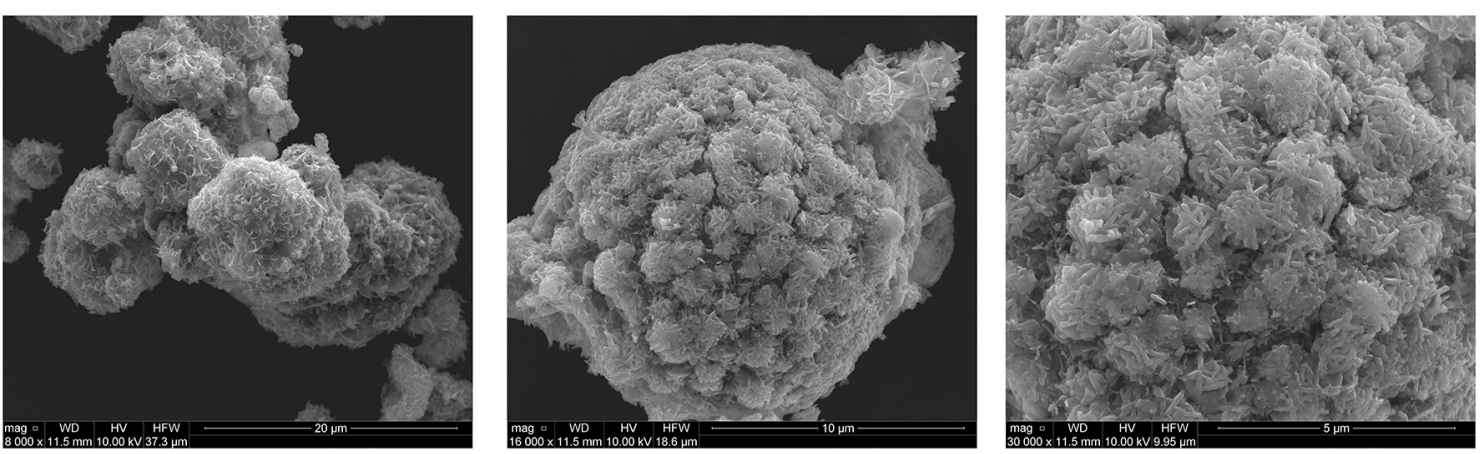

Fig. 7 SEM micrographs of selected best synthesis of Na-A, Na-P1, Na-X and Sodalite 
Weckhuysen and Yu 2015; Abdo and Wilson 2017; Li et al. 2017b).

\section{Conclusions and discussion}

On the basis of the obtained XRD analysis results (for the zeolites obtained from each initial fly ash together with derivatives after grinding), it can be concluded that the most advantageous way of fly ash preparation by grinding using electromagnetic grinder was through the usage of small mills and double cycle of grinding. It can be also stated that in the Na-A zeolite synthesis, the best results were obtained by the following samples: $1004 \mathrm{Na}-\mathrm{A}, 2002$ Na-A, $3003 \mathrm{Na}-\mathrm{A}, 4001 \mathrm{Na}-\mathrm{A}$ and $4004 \mathrm{Na}-\mathrm{A}, 6002 \mathrm{Na}-\mathrm{A}$ and $6004 \mathrm{Na}-\mathrm{A}$. From the class $\mathrm{C}$ fly ash marked as F5000, together with derivatives, the Na-A zeolite was not obtained. Among all Na-A zeolite syntheses, 1004 Na-A has the best properties.

In the case of Na-P1 zeolite synthesis, the best results were obtained by the following samples: $1004 \mathrm{Na}-\mathrm{P} 1,2003$ Na-P1, 3004 Na-P1, 4004 Na-P1, 5004 Na-P1 and 6006 $\mathrm{Na}-\mathrm{P} 1$. Among all Na-P1 zeolite syntheses, the $6006 \mathrm{Na}-\mathrm{P} 1$ sample is characterized by the best properties.

For the Na-X zeolite synthesis, the best results were obtained by the following samples: $1004 \mathrm{Na}-\mathrm{X}, 2004 \mathrm{Na}-$ X, $3004 \mathrm{Na}-\mathrm{X}, 4004 \mathrm{Na}-\mathrm{X}, 5004 \mathrm{Na}-\mathrm{X}$ and $6002 \mathrm{Na}-\mathrm{X}$. Among all Na-X zeolite syntheses, the $3004 \mathrm{Na}-\mathrm{X}$ material is characterized by the best properties.

For the synthesis of the sodalite zeolite, the best results were obtained by the following samples: 1004 SOD, 2004 SOD, 3004 SOD, 4004 SOD, 5002 SOD and 6006 SOD. Among the sodalite zeolite syntheses, the 6006 SOD sample is characterized by the best properties.

The aim of this paper was to investigate the impact of fly ash grinding degree on zeolite synthesis. Special emphasis was paid to insight on quality (crystallinity level, purity) and quantity of final zeolite product after syntheses using several fly ashes and their derivatives after grinding process. For most cases of the conducted series of syntheses, it was found that the fraction of used fly ash has a huge and meaningful impact on the quality and quantity of the obtained zeolites. By providing increasingly finer fly ash enamel particles, a much larger area of ash reaction was obtained. Due to this, much more effective dissolution of the amorphous aluminosilicate enamel was achieved and consequently larger amounts of aluminum and silicon were found in the reaction solution giving basic material to Primary Building Units. At the same time, the fly ash grinding process also allowed the supply of new crystallization centers to the environment of syntheses what resulted in the promotion of heterogeneous nucleation.
Research conducted in this study allowed to deepen and better understand the relationship between the fly ash fraction used as the main substrate and the efficiency of the synthesis of a number of zeolites: Na-A (LTA Group), NaP1 (Gismondine Group), Na-X (Faujasite Group) and Sodalite (Sodalite Group). Obtained results contribute in physicochemical characterization and nature of fly ashes as well as increase the chances of their more effective utilization through conversion to zeolites. The hypothesis that the decrease in the fraction of fly ash used resulted in the formation of zeolite phases with a higher degree of crystals formation, much higher purity and a higher degree of crystallinity was confirmed. It correlates directly with the improvement of physicochemical properties and significantly increases the application potential with a relatively small financial outlay needed to carry out the grinding process of fly ash.

In the next stage of works, the selected fly ash fractions will be tested for the synthesis of zeolites on prototype installation in quarter-technical scale already been reported in previous publication (Wdowin et al. 2014a). Furthermore, economic analysis of the use of zeolites from separated fractions for specific industries will be carried out. In further stages of planned works, a thorough investigation of crystallization centers as well as a comparative impact analysis of the grinding process and the previously described (Czarna-Juszkiewicz et al. 2020) fly ash fractionation process will be carried out.

Acknowledgements This study was financed by The National Center for Research and Development contract No GEKON2/O2/266818/1/ 2015.

Author's contribution Piotr Kunecki: main contractor in grant, laboratory service, operator of research devices, writing text, making figures, calculations. Rafał Panek: second main contractor in grant, laboratory service, operator of research devices, writing text, making figures, calculations. Magdalena Wdowin: Supervision. Tomasz Bień: Magnetic field grinder operator. Wojciech Franus: Supervision, grant manager.

\section{Compliance with ethical standards}

Conflict of interest The authors declare that they have no conflict of interest.

Open Access This article is licensed under a Creative Commons Attribution 4.0 International License, which permits use, sharing, adaptation, distribution and reproduction in any medium or format, as long as you give appropriate credit to the original author(s) and the source, provide a link to the Creative Commons licence, and indicate if changes were made. The images or other third party material in this article are included in the article's Creative Commons licence, unless indicated otherwise in a credit line to the material. If material is not included in the article's Creative Commons licence and your intended use is not permitted by statutory regulation or exceeds the permitted use, you will need to obtain permission directly from the copyright 
holder. To view a copy of this licence, visit http://creativecommons. org/licenses/by/4.0/.

\section{References}

Abdo SF, Wilson ST (2017) Zeolites in Catalysis. In: Čejka J, Morris RE, Nachtigall P (eds) Zeolites in industrial catalysis. Royal Society of Chemistry, Cambridge

Abdulhalim K, Doğruyol M (2014) An experimental study on strength and durability for utilization of fly ash in concrete mix. Adv Mater Sci Eng. https://doi.org/10.1155/2014/417514

Andronikashvili T, Pagava K, Kurashvili T, Eprikashvili L (2009) Possibility of application of natural zeolites for medicinal purposes. Bull Georg Natl Acad Sci 3:158-167

Antiohos SK, Tsimas S (2007) A novel way to upgrade the coarse part of a high calcium fly ash for reuse into cement systems. Waste Manag 27:675-683. https://doi.org/10.1016/j.wasman.2006.03. 016

ASTM International (2015) ASTM C618 - 19. Standard specification for coal fly ash and raw or calcined natural pozzolan for use in concrete

Ates A, Akgül G (2016) Modification of natural zeolite with $\mathrm{NaOH}$ for removal of manganese in drinking water. Powder Technol 287:285-291. https://doi.org/10.1016/j.powtec.2015.10.021

Ayele L, Pérez-Pariente J, Chebude Y, Diaz I (2016) Synthesis of zeolite A using kaolin from Ethiopia and its application in detergents. New J Chem 40:3440-3446. https://doi.org/10.1039/ C5NJ03097H

Backova L, Vandrovcova M, Kopova I, Jirka I (2018) Applications of zeolites in biotechnology and medicine-a review. Biomater Sci 6:974-989. https://doi.org/10.1039/C8BM00028J

Basu M, Pande M, Bhadoria PBS, Mahapatra SC (2009) Potential flyash utilization in agriculture: a global review. Prog Nat Sci 19:1173-1186. https://doi.org/10.1016/j.pnsc.2008.12.006

Behzadfar M, Sadeghi SH, Khanjani MJ, Hazbavi Z (2017) Effects of rates and time of zeolite application on controlling runoff generation and soil loss from a soil subjected to a freeze-thaw cycle. Int Soil Water Conserv Res 5:95-101. https://doi.org/10. 1016/j.iswcr.2017.04.002

Benassi L, Dalipi R, Consigli V et al (2017) Integrated management of ash from industrial and domestic combustion: a new sustainable approach for reducing greenhouse gas emissions from energy conversion. Environ Sci Pollut Res 24:14834-14846. https://doi.org/10.1007/s11356-017-9037-y

Burmańczuk A, Roliński Z, Kowalski C et al (2015) Possibile use of natural zeolites in animal production and environment protection. J Elem 20:803-811. https://doi.org/10.5601/jelem.2014.19.4.759

Cabrera JG, Woolley GR (1994) Fly ash utilisation in civil engineering. Stud Environ Sci 60:345-356. https://doi.org/10. 1016/S0166-1116(08)71470-5

Çelik Ö (2008) Influence of fly ash on the properties of asphalt. Pet Sci Technol 26:1571-1582. https://doi.org/10.1080/ 10916460701287474

Central Statistical Office (2015) Statistical Yearbook of the Republic of Poland

Central Statistical Office (2016) Statistical Yearbook of the Republic of Poland

Central Statistical Office (2017) Statistical Yearbook of the Republic of Poland

Central Statistical Office (2018) Statistical Yearbook of the Republic of Poland

Central Statistical Office (2019) Statistical Yearbook of the Republic of Poland
Czarna D, Baran P, Kunecki P et al (2016) Synthetic zeolites as potential sorbents of mercury from wastewater occurring during wet FGD processes of flue gas. J Clean Prod 172:2636-2645. https://doi.org/10.1016/j.jclepro.2017.11.147

Czarna-Juszkiewicz D, Kunecki P, Panek R et al (2020) Impact of fly ash fractionation on the zeolitization process. Materials (Basel) 13:1035. https://doi.org/10.3390/ma13051035

Dahiya HS, Budania YK (2018) Prospects of fly ash application in agriculture: a global review. Int J Curr Microbiol Appl Sci 7:397-409. https://doi.org/10.20546/ijcmas.2018.710.043

Eprikashvili L, Zautashvili M, Kordzakhia T et al (2016) Intensification of bioproductivity of agricultural cultures by adding natural zeolites and brown coals into soils. Ann Agrar Sci 14:67-71. https://doi.org/10.1016/j.aasci.2016.05.004

EURACOAL statistics (2019a) Coal and lignite production and imports in Europe. https://euracoal.eu/info/euracoal-eu-statistics. Accessed 4 Jul 2019

EURACOAL statistics (2019b) Leading hard coal producing countries worldwide in 2017 (in million metric tons). https://www. statista.com/statistics/264775/top-10-countries-based-on-hardcoal-production. Accessed 4 Jul 2019

EURACOAL statistics (2019c) Effects of coal mining. https://www. eia.gov/energyexplained/index.php?page=coal_environment. Accessed 4 Jul 2019

Feng NQ, Peng GF (2005) Applications of natural zeolite to construction and building materials in China. Constr Build Mater 19:579-584. https://doi.org/10.1016/j.conbuildmat.2005. 01.013

Feng W, Wan Z, Daniels J et al (2018) Synthesis of high quality zeolites from coal fly ash: mobility of hazardous elements and environmental applications. J Clean Prod 202:390-400. https:// doi.org/10.1016/j.jclepro.2018.08.140

Franus W, Wdowin M (2010) Removal of ammonium ions by selected natural and synthetic zeolites. Gospod Surowcami Miner 26:133-148

Franus W, Wdowin M, Franus M (2014) Synthesis and characterization of zeolites prepared from industrial fly ash. Environ Monit Assess 186:5721-5729. https://doi.org/10.1007/s10661-0143815-5

Franus M, Wdowin M, Bandura L, Franus W (2015) Removal of environmental pollutions using zeolites from fly ash: a review. Fresenius Environ Bull 24:854-866

Fruijtier-Pölloth C (2009) The safety of synthetic zeolites used in detergents. Arch Toxicol 83:23-35. https://doi.org/10.1007/ s00204-008-0327-5

Garcia-lodeiro I, Taboada Carcelen V, Fernández-Jiménez A, Ángel P (2017) Recycling industrial by-products in hybrid cements: mechanical and microstructure characterization. Waste Biomass Valor 8:1433-1440. https://doi.org/10.1007/s12649-016-9679-x

Imbabi MS, Carrigan C, McKenna S (2012) Trends and developments in green cement and concrete technology. Int J Sustain Built Environ 1:194-216. https://doi.org/10.1016/j.ijsbe.2013.05.001

Izquierdo M, Querol X (2012) Leaching behaviour of elements from coal combustion fly ash: an overview. Int J Coal Geol 94:54-66

Jiang N, Zhao J, Sun X et al (2017) Use of fly-ash slurry in backfill grouting in coal mines. Heliyon 3:e00470. https://doi.org/10. 1016/j.heliyon.2017.e00470

Joughehdoust S, Manafi S (2008) Iran International Zeolite Conference (IIZC'08) April 29-May1, 2008, Tehran -Iran. In: Application of Zeolite in biomedical engineering: a review

Kesharwani KC, Biswas AK, Chaurasiya A, Rabbani A (2017) Experimental investigation on use of fly ash in concrete. Int Res J Eng Technol 4:1527-1530. https://doi.org/10.17577/ ijertv6is060469 
Kishor P, Ghosh AK, Kumar D (2010) Use of fly ash in agriculture: a way to improve soil fertility and its productivity. Asian J Agric Res 4:1-14. https://doi.org/10.3923/ajar.2010.1.14

Krajišnik D, Daković A, Milić J, Marković M (2019) Zeolites as potential drug carriers. In: Mercurio M, Sarkar B, Langell A (eds) Modified clay and zeolite nanocomposite materials. Elsevier, New York, pp 27-55

Kraljević Pavelić S, Simović Medica J, Gumbarević D et al (2018) Critical review on zeolite clinoptilolite safety and medical applications in vivo. Front Pharmacol. https://doi.org/10.3389/ fphar.2018.01350

Kuley E, Ozogul F, Durmus M et al (2012) The impact of applying natural clinoptilolite (zeolite) on the chemical, sensory and microbiological changes of vacuum packed sardine fillets. Int $\mathbf{J}$ Food Sci Technol 47:1977-1985. https://doi.org/10.1111/j.13652621.2012.03060.x

Kunecki P, Panek R, Wdowin M, Franus W (2017) Synthesis of faujasite (FAU) and tschernichite (LTA) type zeolites as a potential direction of the development of lime Class $\mathrm{C}$ fly ash. Int J Miner Process. https://doi.org/10.1016/j.minpro.2017.07. 007

Kunecki P, Panek R, Koteja A, Franus W (2018) Influence of the reaction time on the crystal structure of Na-P1 zeolite obtained from coal fly ash microspheres. Microporous Mesoporous Mater 266:102-108. https://doi.org/10.1016/j.micromeso.2018.02.043

Li J, Zhuang X, Querol X et al (2017a) A review on the applications of coal combustion products in China. Int Geol Rev 60:671-716. https://doi.org/10.1080/00206814.2017.1309997

Li Y, Li L, Yu J (2017b) Applications of Zeolites in sustainable chemistry. Chemistry 3:928-949. https://doi.org/10.1016/j. chempr.2017.10.009

Linek M, Żebrowski W, Wolka P (2018) The application of natural zeolite to cement concrete intended for communications surfaces. In: Słyś D, Dziopk J (eds) E3S web of conferences

Maèala J, Pandová I, Panda A (2009) Clinoptilolite as a mineral usable for cleaning of exhaust gases. Gospod Surowcami Miner 25:23-32

Markiv T, Sobol K, Franus M, Franus W (2016) Mechanical and durability properties of concretes incorporating natural zeolite. Arch Civ Mech Eng 16:554-562

Miranda T, Silva RA, Oliveira DV et al (2017) Construction and building materials. Constr Build Mater 155:65-78

Mistry R, Roy TK (2016) Effect of using fly ash as alternative filler in hot mix asphalt. Perspect Sci 8:307-309. https://doi.org/10.1016/ j.pisc.2016.04.061

Mohammadinia A, Arulrajah A, Horpibulsuk S, Chinkulkijniwat A (2017) Effect of fly ash on properties of crushed brick and reclaimed asphalt in pavement base/subbase applications. J Hazard Mater 321:547-556. https://doi.org/10.1016/j.jhazmat. 2016.09.039

Mohammadkhani B, Tabesh H, Houshmand B, Mohammadkhani B (2016) Investigation on novel applications of zeolites in advanced medical sciences. Res Med 40:96-108

Murayama N, Yamamoto H, Shibata J (2002) Zeolite synthesis from coal fly ash by hydrothermal reaction using various alkali sources. J Chem Technol Biotechnol 77:280-286. https://doi.org/ $10.1002 / j \mathrm{jctb} .604$

Nakhli SAA, Delkash M, Bakhshayesh BE, Kazemian H (2017) Application of zeolites for sustainable agriculture: a review on water and nutrient retention. Water Air Soil Pollut. https://doi. org/10.1007/s11270-017-3649-1

Pavelić K, Hadzija M (2010) Medical applications of zeolites. In: Handbook of zeolite science and technology, Chapter 24

Payra P, Dutta P (2003) Handbook of zeolite science and technology. In: Auerbach SM, Carrado KA, Dutta PK (eds) Chapter I: Zeolites: a primer. CRC Press, Boca Raton
Querol X, Moreno N, Umaña J et al (2002) Synthesis of zeolites from coal fly ash: an overview. Int J Coal Geol 50:413-423. https:// doi.org/10.1016/S0166-5162(02)00124-6

Ram LC, Masto RE (2010) An appraisal of the potential use of fly ash for reclaiming coal mine spoil. J Environ Manage 91:603-617. https://doi.org/10.1016/j.jenvman.2009.10.004

Ramesh K, Reddy DD (2011) Zeolites and Their Potential Uses in Agriculture. Adv Agron 113:215-236. https://doi.org/10.1016/ B978-0-12-386473-4.00009-9

Sato A, Nishimoto S (2005) Effective reuse of coal ash as civil engineering material. In: Proceedings of the world of coal ash conference

Sekhon BS, Sangha MK (2008) Detergents-Zeolites and enzymes excel cleaning power. Resonance 9:35-45. https://doi.org/10. 1007/bf02837576

Selvam T, Schwieger W, Dathe W (2014) Natural Cuban zeolites for medical use and their histamine binding capacity. Clay Miner 49:501-512. https://doi.org/10.1180/claymin.2014.049.4.01

Sengoz B, Topal A, Gorkem C (2013) Evaluation of natural zeolite as warm mix asphalt additive and its comparison with other warm mix additives. Constr Build Mater 43:242-252. https://doi.org/ 10.1016/j.conbuildmat.2013.02.026

Shang JQ (2016) Application of coal fly ash to replace lime in the management of reactive mine tailings. In: Fourth Geo-China international conference. https://doi.org/10.1061/ 9780784480069.001

Shi W, Shao H, Li H et al (2009) Progress in the remediation of hazardous heavy metal-polluted soils by natural zeolite. J Hazard Mater 170:1-6. https://doi.org/10.1016/j.jhazmat.2009.04.097

Singh JS, Pandey VC (2013) Fly ash application in nutrient poor agriculture soils: impact on methanotrophs population dynamics and paddy yields. Ecotoxicol Environ Saf 89:43-51. https://doi. org/10.1016/j.ecoenv.2012.11.011

Singh RP, Sharma B, Sarkar A et al (2014) Biological responses of agricultural soils to fly-ash amendment. Rev Environ Contam Toxicol 232:45-60. https://doi.org/10.1007/978-1-4419-8011-3

Szczygielski T (2015) Minerały antropogeniczne a gospodarka w obiegu zamkniętym. Materiały Budowlane 12:34-36. https://doi. org/10.15199/33.2015.12.10

Tanijaya J, Jardjito D (2008) Experimental study on the use of natural zeolites as partial replacement for cement in concrete. In: Eleventh East Asia-pacific conference on structural engineering and construction (EASEC-11) "Building a Sustainable Environment" November 19-21, 2008, Taipei, TAIWAN

Topal A, Sengoz B, Kok BV et al (2014) Evaluation of mixture characteristics of warm mix asphalt involving natural and synthetic zeolite additives. Constr Build Mater 57:38-44. https://doi.org/10.1016/j.conbuildmat.2014.01.093

Van Dalen G, Vooijs C (2000) Determination of the zeolite and silicate content in detergent products by wavelength-dispersive x-ray fluorescence spectrometry. X-Ray Spectrom 29:365-372. https://doi.org/10.1002/1097-4539(200009/10)29:5\%3c365: AID-XRS441\%3e3.0.CO;2-Q

Van den Berger JW, Cornelissen HAW (1999) Effect of low NOx Technologies on Fly ash Quality. In: 13th international symposium on use and management on CoalCombustion products. p 291

Wdowin M (2020) Popioły lotne jako substrat w procesie wytwarzania krzemianowych sorbentów w zastosowaniach sektora energetycznego. Energ Ciepl i Zawodowa 2

Wdowin M, Franus M, Panek R et al (2014a) The conversion technology of fly ash into zeolites. Clean Technol Environ Policy 16:1217-1223. https://doi.org/10.1007/s10098-014-0719-6

Wdowin M, Wiatros-Motyka MM, Panek R et al (2014b) Experimental study of mercury removal from exhaust gases. Fuel 128:451-457. https://doi.org/10.1016/j.fuel.2014.03.041 
Weckhuysen BM, Yu J (2015) Recent advances in zeolite chemistry and catalysis. Chem Soc Rev 44:7022-7024. https://doi.org/10. 1039/C5CS90100F

Woszuk A (2018) Application of fly ash derived zeolites in warm-mix asphalt technology. Materials (Basel) 11:1542. https://doi.org/ $10.3390 /$ ma1 1091542

Woszuk A, Franus W (2016) Properties of the warm mix asphalt involving clinoptilolite and Na-P1 zeolite additives. Constr Build Mater 114:556-563. https://doi.org/10.1016/j.conbuildmat.2016. 03.188

Woszuk A, Franus W (2017) A review of the application of zeolite materials in warm mix asphalt technologies. Appl Sci 7:293. https://doi.org/10.3390/app7030293
Woszuk A, Zofka A, Bandura L, Franus W (2017) Effect of zeolite properties on asphalt foaming. Constr Build Mater 139:247-255. https://doi.org/10.1016/j.conbuildmat.2017.02.054

Yilmaz B, Müller U (2009) Catalytic applications of zeolites in chemical industry. Top Catal 52:888-895. https://doi.org/10. 1007/s11244-009-9226-0

Yunusa IAM, Loganathan P, Nissanka SP et al (2012) Application of coal fly ash in agriculture: a strategic perspective. Crit Rev Environ Sci Technol 42:559-600. https://doi.org/10.1080/ 10643389.2010.520236 